\title{
Church Building and Wine Making East of Ankara Regional Aspects of Central Anatolia in the Early Byzantine Period
}

\author{
Stephen MITCHELL* - Philipp NIEWÖHNER*** \\ Ali VARDAR ${ }^{* * *}$ - Levent Egemen VARDAR ${ }^{* * * *}$
}

\section{Introduction}

The Byzantine archaeology of central Anatolia gathered pace at the turn of the twentieth century, when various travellers started to report Christian monuments in greater numbers. This prompted J. Strzygowski to pronounce Asia Minor a "Neuland der Kunstgeschichte" and to focus his analysis of the region on churches in central Anatolia. ${ }^{1}$ However, as more monuments became known all over Asia Minor, including the coastal provinces, central Anatolia began to be perceived as different, odd, and primitive. Writing half a century after Stzygowski, R. Krautheimer dismissed the early Christian architecture of central Anatolia as a "backwater offshoot". ${ }^{2}$

It took another half a century and the publication of many more monuments, until it transpired that early Christian art and architecture knew no empire-wide standard, but was organized on a provincial level, the same as the early church. As each province elected its own priests, bishops, and metropolitans, it also established its own brand of Christian church building and decoration. ${ }^{3}$ Regional diversity was as typical of central Anatolia as it was of so many other parts of the far-flung empire and early Christianity.

The worthiness of central Anatolia as an early Christian Kunstlandschaft in its own right was initially recognized for its inscriptions, the first monuments to be recorded and published in great numbers from this region. ${ }^{4}$ The more recent flourishing of early Byzantine archaeology in Turkey is now revealing the same for early Christian churches in central Anatolia; they are starting to be recognized for their distinctive features that are neither odd nor primitive, for example

*Prof. Dr. Stephen Mitchell, Berlin (mitchank@gmail.com; https://orcid.org/0000-0001-9623-0983).

** PD Dr. Philipp Niewöhner, Georg-August Universität, Göttingen (philippniewoehner@hotmail.com).

*** Ali Vardar, Hamburg (vardarali@hotmail.com; https://orcid.org/0000-0002-0100-2548).

***** Levent Egemen Vardar, Kültür ve Turizm Bakanlığı; Kültür Varlıkları ve Müzeler Genel Müdürlüğü, Kazılar Dairesi Başkanlı̆̆ı, Ankara (lvardar@hotmail.com; https://orcid.org/0000-0003-3857-3763).

${ }^{1}$ Strzygowski 1903.

${ }^{2}$ Krautheimer 1986, 162-166.

${ }^{3}$ Niewöhner in press a.

${ }^{4}$ Starting with the pioneering work of W. M. Ramsay and the epigraphers of the Monumenta Asiae Minoris Antiqua series. For bibliography and some more recent evaluations, see Mitchell 1993; Breytenbach - Zimmermann 2017. 
extra wide narthexes that sometimes accommodated staircases and thus appear to indicate that Anatolian churches had galleries. ${ }^{5}$

Other regional characteristics are evident in the liturgical furnishings of early Christian churches, e.g. the way that ambos were made and decorated. Central Anatolian ambos were functionally equivalent to lecterns at Constantinople or in the Aegean province of Caria, for example, but they had a different construction and appearance. The most important producers of Anatolian ambos appear to have been at Docimium in Phrygia, the leading marble quarry and workshop complex on the plateau that was imitated by numerous local workshops throughout the region. ${ }^{6}$ Docimium also produced column capitals in the style that is known from the metropolitan quarries of Proconnesus near Constantinople, ${ }^{7}$ and the two workshops must have been closely related, possibly through the imperial estate that is known to have had stakes in both quarries during the Roman period. ${ }^{8}$ Thus, Docimium would surely have been able to turn out the same kind of lectern as Proconnesus did for Constantinople, and the different Anatolian ambos appear to have been a matter of choice and provincial distinctiveness. ${ }^{9}$

This paper adds two more elements to the characterization of early Christian Anatolia, fluted column capitals and decorated press weights. Fluted capitals are similar to ambos in so far as some of them seem to have been liturgical furnishings. However, the capitals have no apparent relation to Docimium and thus show that the idiosyncrasies of Anatolian church fittings did not depend on a single workshop alone. This is confirmed by the press weights that are decorated with Christian symbols and inscriptions and attest to numerous local workshops in rural Anatolia that employed their own regional repertoires.

The following elaborates these points with reference to two dozen recent finds from a survey in the rural hinterland to the east of Ankyra/Ankara (Fig. 1), which are here published for the first time. The survey was conducted chiefly by Ali and Levent Egemen Vardar in 2004 and 2005. ${ }^{10}$ Stephen Mitchell and Philipp Niewöhner have helped to prepare this publication by contributing their respective expertise in epigraphy and Byzantine carvings. ${ }^{11}$

\section{Fluted Capitals}

Fluted capitals are surrounded by a ring of vertical flutes. This is combined with a square top (Fig. 1-8) more often than with a concave abacus. In the early Byzantine period, the type was

\footnotetext{
${ }^{5}$ Bell - Ramsay 1909, 41-50 fig. 130, 164; Eyice 1971; Ivantchik - von Kienlin - Summerer 2010, 128131; Niewöhner 2013b, 105, 128.

${ }^{6}$ Niewöhner 2014.

${ }^{7}$ Niewöhner 2007, 120-127.

${ }^{8}$ Fant 1988; Fant 1989, 157-160 (Docimium), 164-165 (Proconnesus); Drew-Bear 1994; Hirt 2010, 291-307, 318-323 (Docimium); Russell 2013, 38-52.

${ }^{9}$ Niewöhner 2013a.

${ }^{10}$ For preliminary reports, see Vardar 2005; Vardar 2006.

${ }^{11}$ Niewöhner did this as part of a research project funded by the Deutsche Forschungsgemeinschaft (DFG, German Research Foundation), Projektnummer 406117376. Mitchell carried out survey work in the region between 1970 and 1972 .
} 
popular with provincial workshops in western Asia Minor and central Anatolia. ${ }^{12}$ It may have come about as a simplified form of the Roman Blattkelch capital. ${ }^{13}$ Originally, the type goes back to Egyptian palm leaf capitals with square tops, and some more deeply undercut and hollowed out flutes appear to resemble palm leaves (Fig. 2. 6). The same tradition also accounts for the lancet leaves that serve as spacers of more elaborate flutes (Fig. 2. 4. 6). More basic Byzantine specimens reduced the flutes to simple grooves (Fig. 4), and the lancet leaves may be omitted completely (Fig. 3. 5. 8)

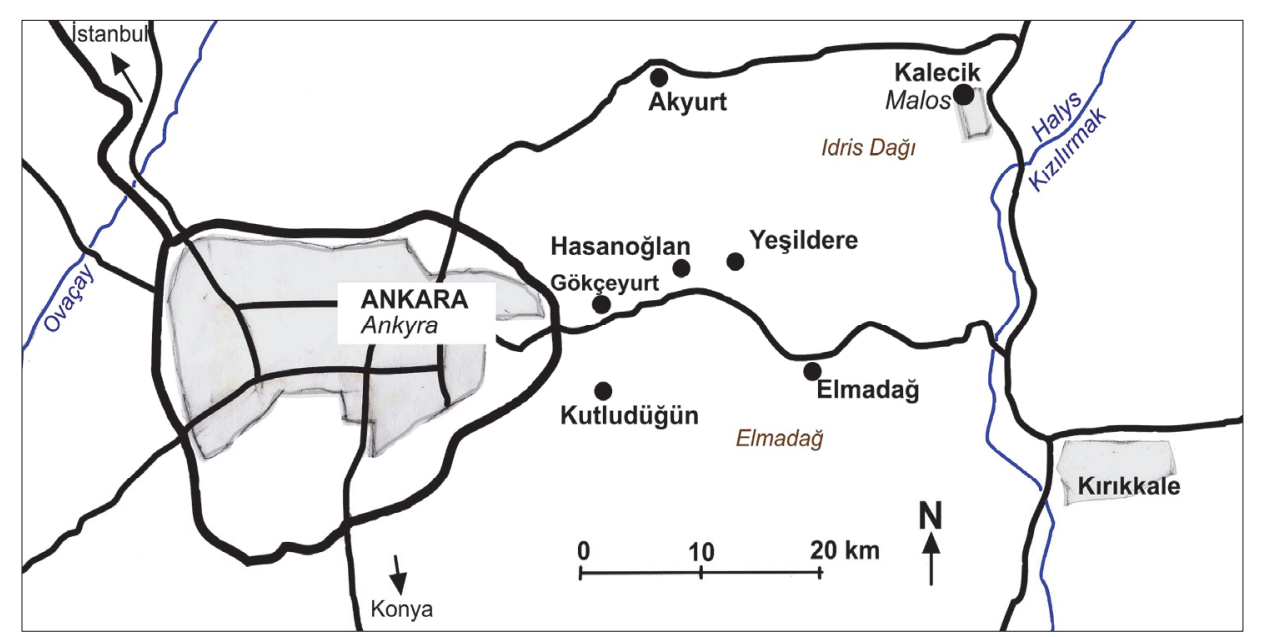

Fig. 1) The survey area lies east of Ankara, as far as the Halys/Kızllırmak river, and includes the Idris Dağı and the Elmadağ mountains as well as various Turkish villages and towns, where the artefacts are kept (map: A. Vardar). The black lines indicate modern roads

In western Asia Minor, the fluted décor was an alternative to many contemporary Byzantine forms and in some cases appears to have been chosen in order to reference local tradition rather than follow the latest fashion from Constantinople. One case in point is the seventh-century basilica of St Michael at Miletus in Caria that combined fluted capitals with fluted friezes on an architrave, all of which were old-fashioned elements and corresponded with neighbouring Roman monuments that also employed architraves with fluted friezes. ${ }^{14}$ In central Anatolia, fluting was more common than in western Asia Minor and appears to have been a standard form of décor in the early Byzantine period. It would thus not have had the same antiquarian associations as at Miletus. The many rural finds of fluted capitals ${ }^{15}$ would in any case have lacked ancient reference points, as architectural sculpture had mostly been an urban prerogative in central Anatolia, until churches started to be built in villages, too. The ninth- or tenth-century urban church of St Clement at Ankara, although it had fluted capitals and cornices like St Michael at Miletus, did not employ architraves but arcades and domed vaulting and would seem to have formed a modern interior which complied with what was then the latest fashion. ${ }^{16}$

\footnotetext{
${ }^{12}$ Styan 1987; Niewöhner 2007, 173-175 with extensive earlier bibliography.

${ }^{13}$ Börker 1965; Liljenstolpe 1996-1998.

${ }^{14}$ Niewöhner 2016, 37-57, 114-115; Niewöhner 2018, 198.

${ }^{15}$ Keskin no date.

16 Peschlow 2015, 222-224. See also, for a possible foundation date around 976, Mitchell - French 2012-2019, vol. 2 no. 502.
} 
The popularity of fluted décor in central Anatolia is also confirmed by the widespread use of small fluted capitals with additional décor on unusually high square tops. Some tops are for example decorated with crosses in wreaths, ${ }^{17}$ resembling concave abaci, others display votive inscriptions (Fig. 6-8). The additional décor of symbols and inscriptions confirms that all these capitals were employed in churches. Their small dimensions and the legibility of the inscriptions suggest that they belonged to liturgical furnishings, e.g. to ciboria or canopies above altars, and to sanctuary screens in the form of templa, whose marble parts often carried votive inscriptions. ${ }^{18}$ This use of fluted capitals for liturgical furnishing and as a preferred location for inscriptions appears to have been a central Anatolian peculiarity.

The inscription on a small fluted capital at Elmadağ (Fig. 6. 7) was first published as RECAM II 217, copy of SM 1972 (PH 267852; ICG 2383):

$$
\begin{aligned}
& \Psi \dot{v} \pi \dot{\varepsilon} \rho \varepsilon \dot{v}\{\varphi\} \chi \eta \tilde{\eta} \varsigma \operatorname{Ka} \lambda[\ldots] \\
& \text { OPOГENOY }
\end{aligned}
$$

The character originally recorded as a broken phi must be a cross, and it is not difficult to restore the missing letters at the end of the first line to read

$$
\begin{aligned}
& \Psi \dot{v} \pi \dot{\varepsilon} \rho \varepsilon \dot{u} \Psi \chi \tilde{\eta} \varsigma \operatorname{Ka} \lambda[\tilde{\eta} \varsigma \text { †] } \\
& \text { 'Opoүévou }
\end{aligned}
$$

To fulfil a vow of Kale, daughter of Orogenes.

The inscription on a half-finished small fluted column capital at Yeşildere (Fig. 8) reads

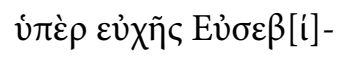

$$
\begin{aligned}
& \text { ov } \pi \varepsilon \rho\llcorner o \delta \varepsilon v \tau o \tilde{~}
\end{aligned}
$$

To fulfil a vow of Eusebius, the peripatetic (priest).

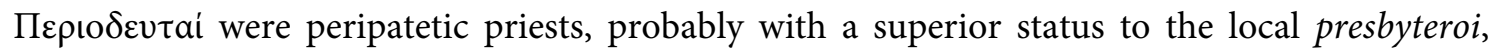
whose responsibilities perhaps covered several villages, and are attested by many inscriptions especially in Asia Minor and the Near East. In Anatolia, there are examples at Pessinus, in eastern Galatia, at Arabsefer, a village between Yozgat and Amasya, in Lycaonia, and at Anazarbus in Cilicia. ${ }^{19}$ The individuals mentioned at Pessinus, in Lycaonia, and at Anazarbus explicitly combined the roles of periodeutes and presbyteros. ${ }^{20}$

\footnotetext{
${ }^{17}$ Keskin 2015.

${ }^{18} \mathrm{Cf}$. in particular a small column capital with votive inscription imported from Constantinople for the liturgical furnishing of San Clemente at Rome: Barsanti - Flaminio - Guiglia 2015, 264-274 cat. 130 pl. 68.

${ }^{19}$ Pessinus: I. Pessinus 34; Arapsefer: Hirschfeld 1888, 891, 68; Lycaonia: MAMA VIII 303 (Seçme); Anazarbos: I. Cilicie 117 = SEG 37, 1255, dated AD 490/1.

${ }^{20}$ See also Feissel 2006, 684 (Ptolemais in Phoenicia Maritima).
} 


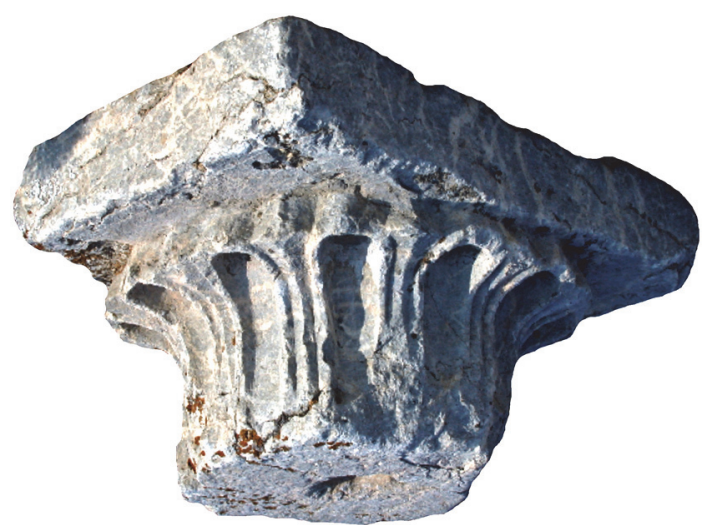

Fig. 2) Fluted column capital with lancet leaves as spacers, in the municipal park at Elmadăg (photo: L. E. Vardar 2004)

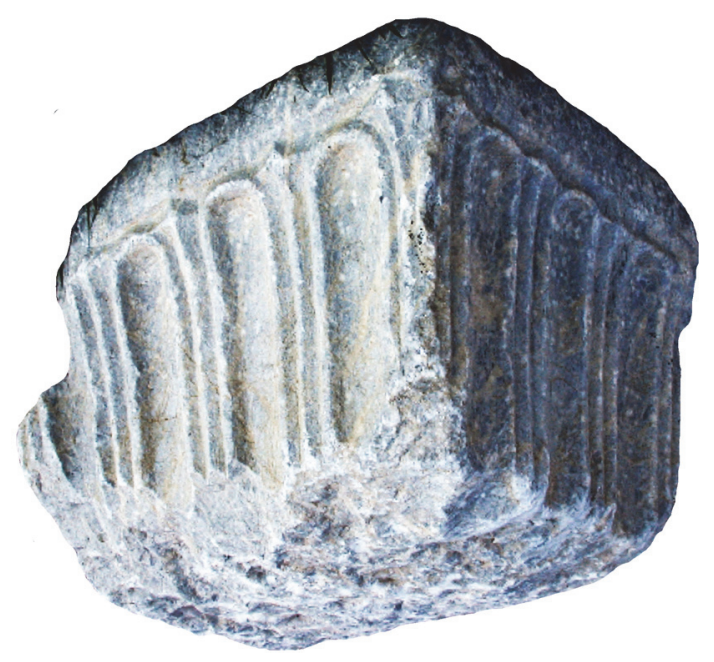

Fig. 4) Fluted pier capital with lancet leaves as spacers, in the municipal park at Elmada ğ (photo: L. E. Vardar 2004)

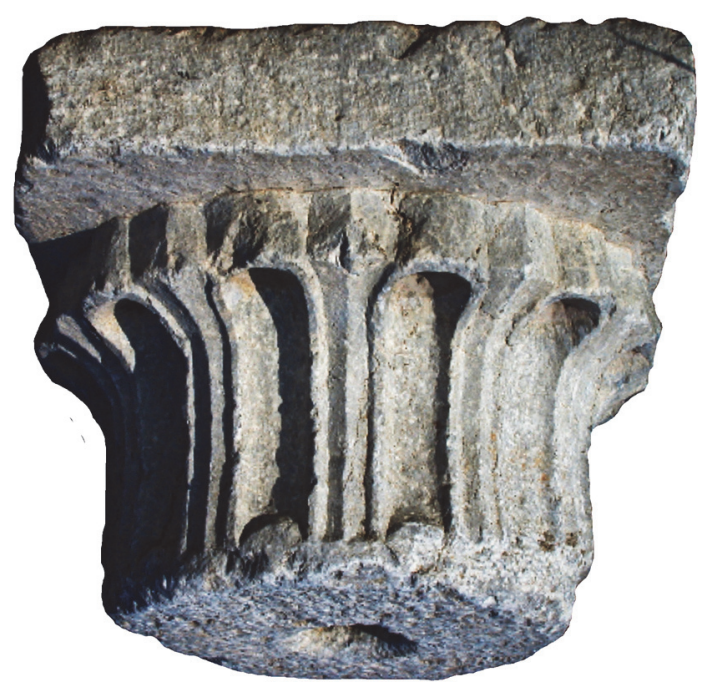

Fig. 6) Small fluted column capital with lancet leaves as spacers, in the municipal park at Elmadağ (photo: L. E. Vardar 2004). H. 39, W. 49, D. 60. The other side with inscription on top, see the following figure

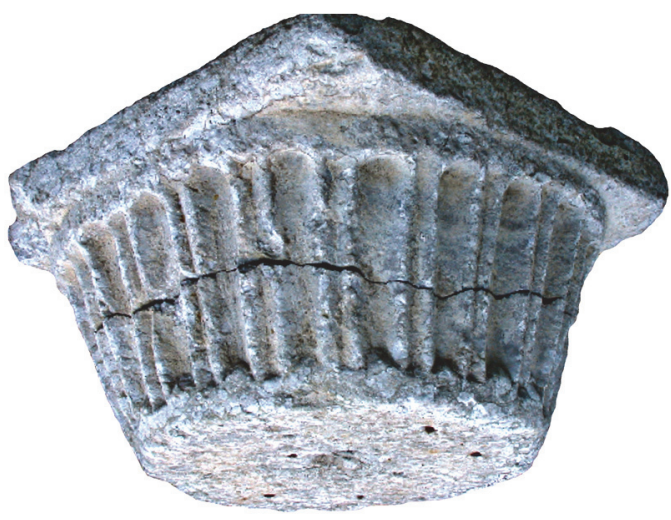

Fig. 3) Fluted column capital (without spacers), in the municipal park at Yeşildere, previously called Dereşıh (photo: L. E. Vardar 2004)

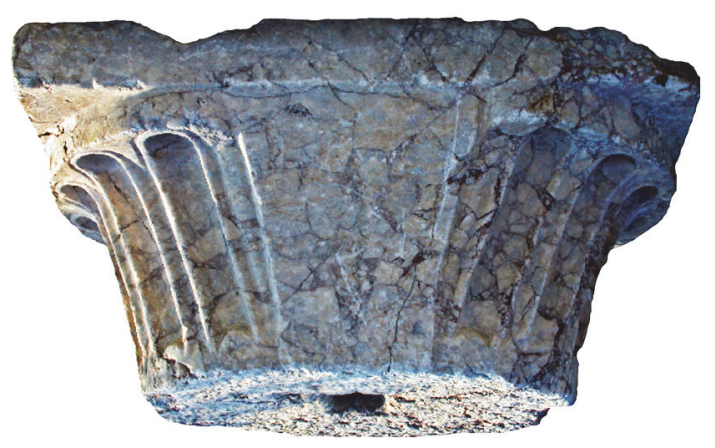

Fig. 5) Fluted mullion capital (without spacers), colourful breccia, in the municipal park at Elmadağ (photo: L. E. Vardar 2004)

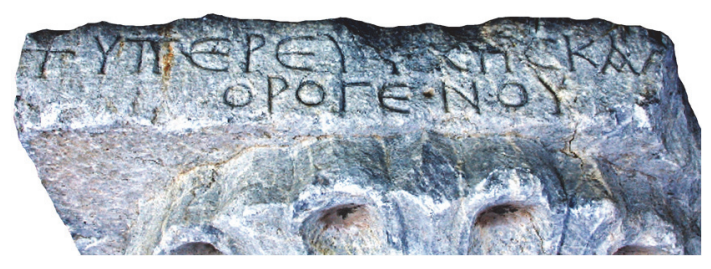

Fig. 7) Inscription on top of the small fluted column capital in the previous figure (photo: L. E. Vardar 2004). Letters 3,5 


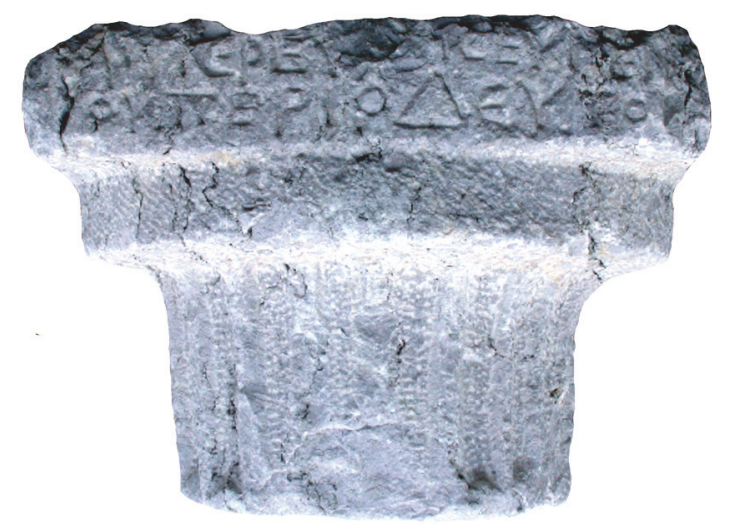

Fig. 8) Half-finished small fluted column capital with inscription on top, in the municipal park at Yeşildere, previously called Dereşı (photo: L. E. Vardar 2004)

\section{Press Weights with Crosses}

Large stone weights that anchored the lifting booms of screw presses for oil and wine are identified by a central rotating pan for the spindle and by flanking dovetailed sockets that served to attach the thread. The dovetailed sockets could take various shapes, but in the area of this survey, they are mostly combined with the rotating pan to form a keyhole-shaped cavity (Fig. 14. 22. 24). In some cases, the keyhole is flanked by four additional dowel (?) holes (Fig. 18. 28). ${ }^{21}$ These holes made the top the most fragile part of the otherwise solid weights and it often broke (Fig. 12. 19. 20. 28. 30-33). ${ }^{22}$ In other instances, the top has been hollowed out in Turkish times to be re-used as a mortar (Fig. 15. 16. 19) for pounding and crushing bulgur with a large wooden pestle or hammer (Fig. 17).

Press weights were common in the wider Mediterranean region and are mostly plain, ${ }^{23}$ but in Asia Minor and Constantinople they can be decorated with crosses (Fig. 12. 16. 19-23. 25-27. 30-33), cross medallions (Fig. 18. 29), crosses on globes (Fig. 9), and floral motives (Fig. 9-11. 19. 25-28. 30-33). ${ }^{24}$ The decor often goes hand in hand with special, polygonal forms (Fig. 9-16. 2533) and is sometimes combined with niches and aediculae (Fig. 23. 24) ${ }^{25}$ Polygonal weights were practical when it came to walking around them and turning the spindle, and some weights appear to have been carved in this shape although they were not subsequently decorated (Fig. 13. 14. 15).

The regional distribution of press weights decorated with crosses in Asia Minor clusters in central Anatolia with dozens of examples. In contrast, the Mediterranean provinces along the west and south coasts of Turkey have yielded few specimens, the most noticeable exceptions being

${ }^{21}$ Cf. Niewöhner 2020, 332 fig. 12. For a technical explanation of the small additional holes, see Frankel 1999, 119.

${ }^{22}$ Cf. Niewöhner 2020, 331-333 fig. 10-13.

${ }^{23}$ Ayalon - Frankel - Kloner 2009, with extensive earlier bibliography.

${ }^{24}$ Niewöhner 2017; Niewöhner 2020.

${ }^{25}$ Cf. Niewöhner 2020, 331 fig. 10. 
three cross stones in and near Nicaea/Iznik in Bithynia ${ }^{26}$ as well as a couple of museum pieces at Istanbul. ${ }^{27}$ This uneven distribution is the more remarkable, as the Mediterranean provinces are generally better known through more numerous excavations and surveys. That so few cross stones have come to light there would seem to be a valid argumentum ex silentio, suggesting that Christian decoration of press weights was mainly a central Anatolian custom. ${ }^{28}$ As such, it could be recognized as a distinctive regional feature, like the fluted capitals, central Anatolian ambos, vaulted basilicas with mullions, and wide narthexes, all of which would have combined to set the high plateau apart from the various Christian traditions of the coastal provinces.

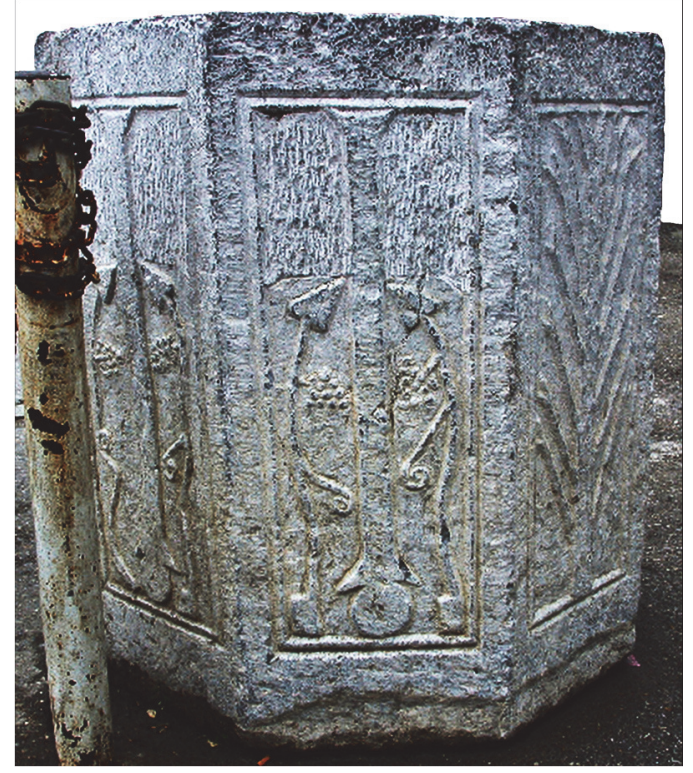

Fig. 9) Octagonal press weight with keyhole-shaped cavity on top, now filled with concrete, 2004 and 2016 in front of the municipal building at Kutludüğ̈̈n (photo: L. E. Vardar 2004). Three neighbouring sides (the front) each have a picture panel carved with a cross on a globe and flanking ivy, the horizontal cross bars erased (two of these front sides are visible on the left side of the photograph); the next side to the right shows a bare tree with upturned branches, also inside a panel (right side of the photograph); for more sides, see the following figures. H 94, $\varnothing$ $86 / 7$, W of one side 37

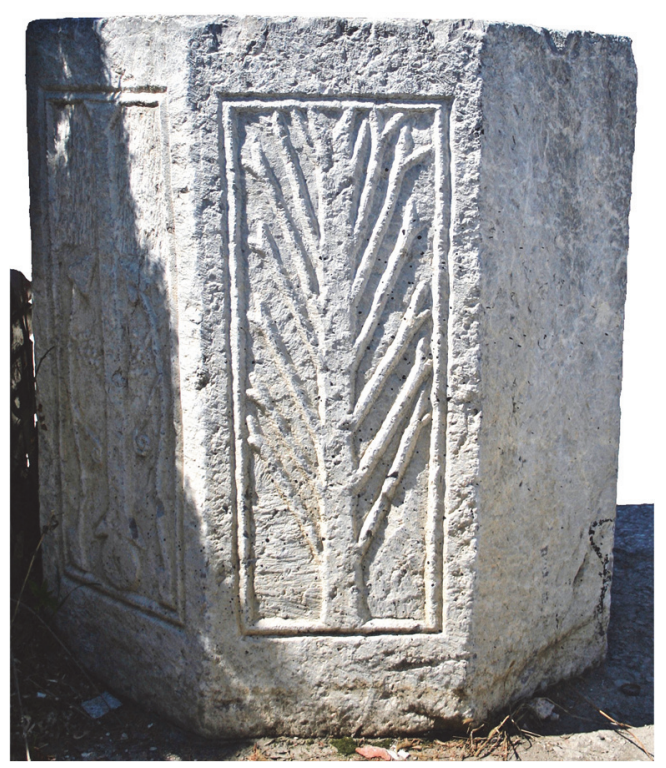

Fig. 10) Three sides of the octagonal press weight in the previous figure (photo: S. Mitchell 2016): The front with three crosses (one of which is visible on the left side of the photograph) is followed on the right by a leafless tree inside a picture panel (centre of the photograph); the side after this is left blank (right side of the photograph)

More particularly, the press weights under consideration here attest to the spread and importance of viticulture in the survey area. Presses themselves are not normally discovered, unless as chance finds in archaeological excavations or because they survive in rock-cut ensembles, for example at Amorium in Phrygia, in north-western Galatia, and in Cappadocia. ${ }^{29}$ Neither applies to the survey area, but four inscribed press weights provide other, additional insights into local

\footnotetext{
${ }^{26}$ Altın - Şahin 2018; Şahin 2019, 85 f. 95 fig. 5; Niewöhner 2020, 330 fig. 7.

${ }^{27}$ Niewöhner 2020, 331-333 fig. 10-13.

${ }^{28}$ Regional variability was common in ancient presses, see Lewit 2020.

${ }^{29}$ Ivison 2012, 47-50; Peker 2020; Niewöhner - Vardar in press.
} 
conditions. Inscribed weights are not (yet) known elsewhere and thus appear to confirm that the decoration of presses was a regional phenomenon. The inscriptions also help to answer the question why the weights were decorated at all.

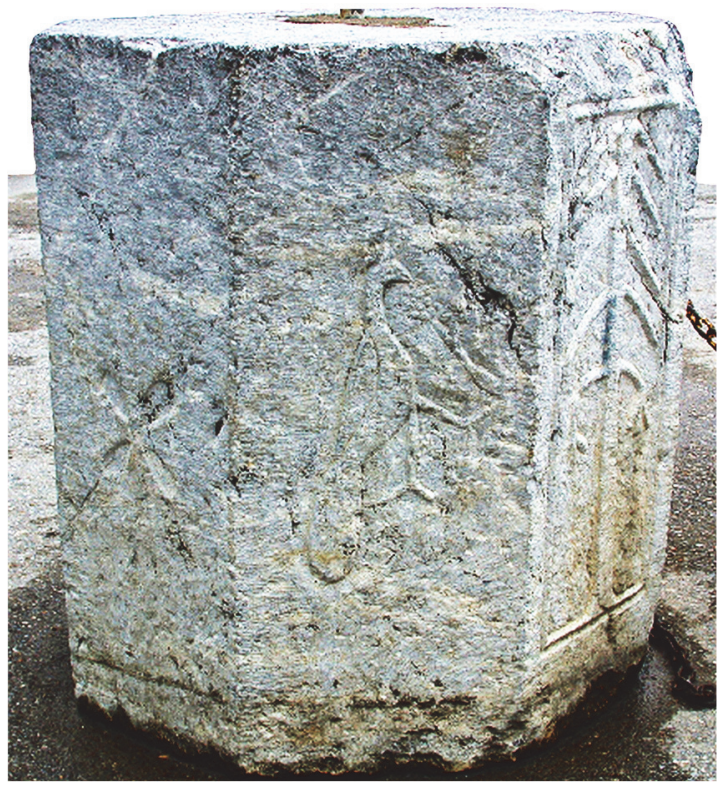

Fig. 11) Three more sides of the octagonal press weight in the previous figures (photo: L. E. Vardar 2004): To the left of the three front sides with crosses (to the right of the photograph) follows yet another panelled side with a tree, same as on the opposite right side, but here the branches are turning downwards and have two three-lobed leaves. The next side (in the centre of the photograph) shows a peacock picking grapes, the last side (on the left of the photograph) a four-petalled flower

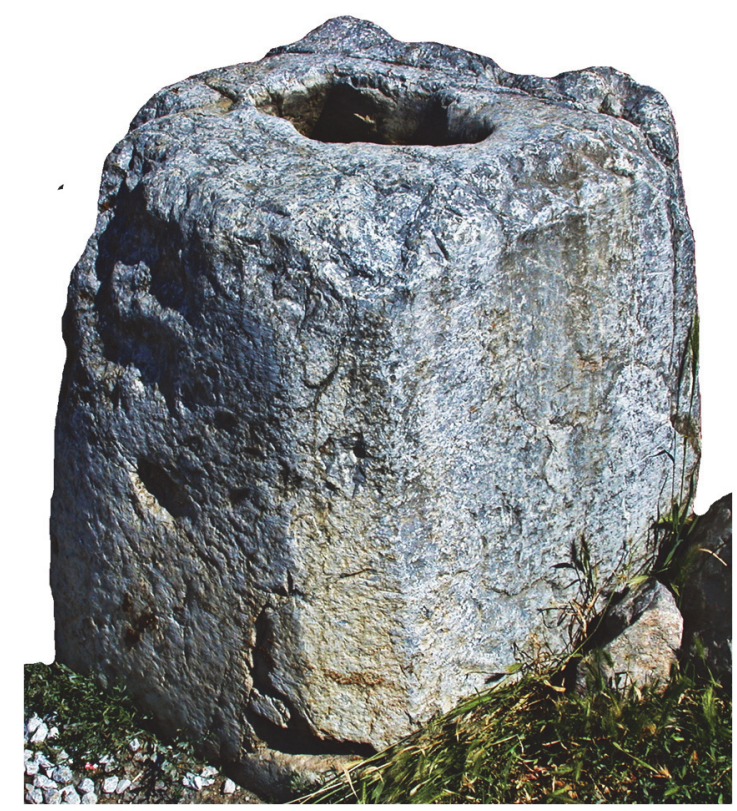

Fig. 13) Rectangular press weight with bevelled edges and keyhole-shaped cavity on top, at Akyurt, previously called Ravlı (photo: L. E. Vardar 2005)

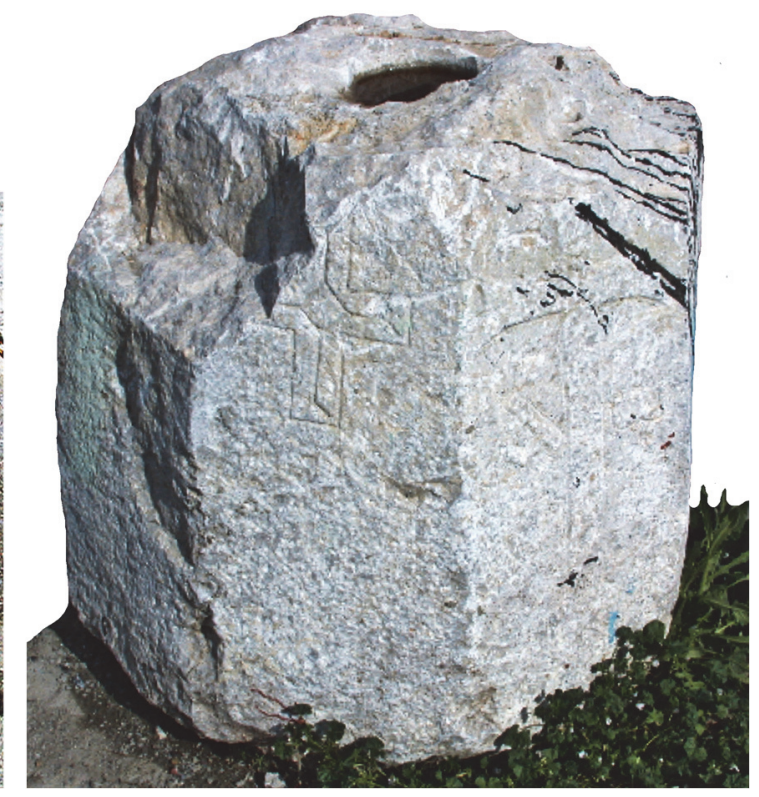

Fig. 12) Octagonal cross stone with cup-shaped cavity on the otherwise broken top, in the municipal park at Yeşildere, previously called Dereşı (photo: L. E. Vardar 2004). The front with a large cross in high relief (right side of the photograph), the two flanking sides each with a smaller incised cross (one in the centre of the photograph), the remaining sides blank or broken, some black oil paint

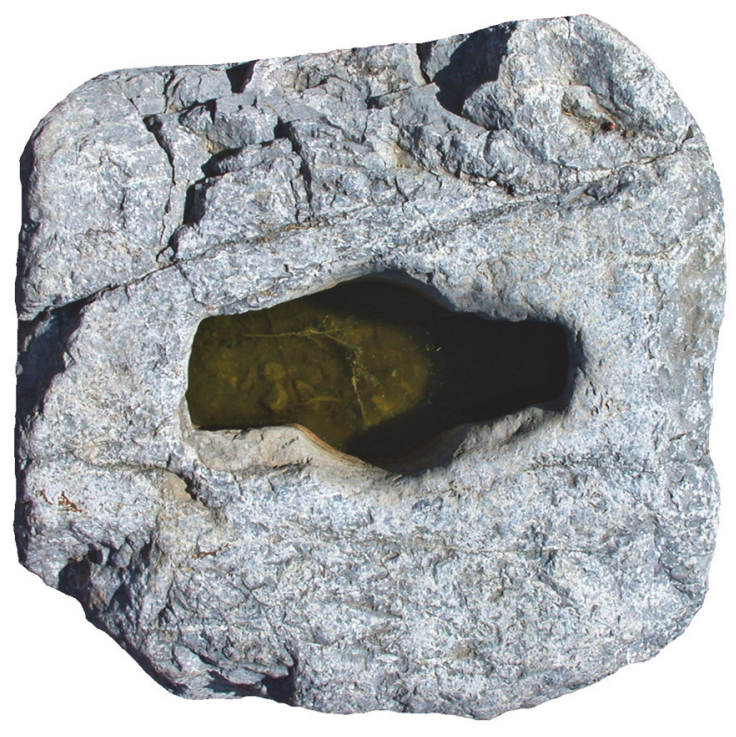

Fig. 14) Top view of the press weight in the previous figure (photo: L. E. Vardar 2005) 


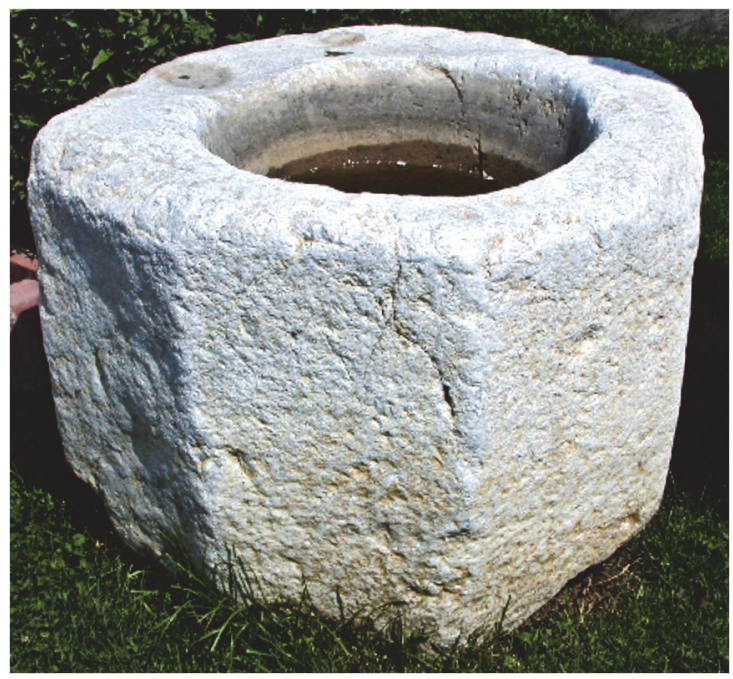

Fig. 15) Octagonal stone, in the municipal park at Hasanoğlan (photo: L. E. Vardar 2004). All sides blank, the top later hollowed out as mortar for bulgur

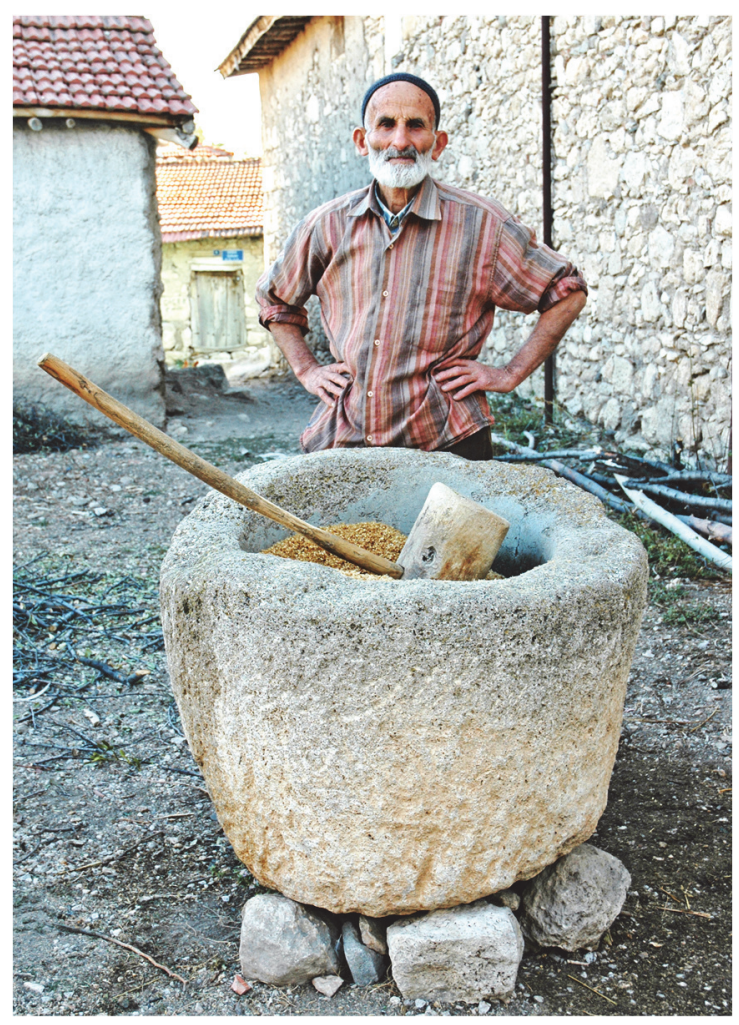

Fig. 17) A stone mortar and wooden hammer used for the pounding and crushing of bulgur, at Kayakent in the vicinity of Germia, southwestern Galatia (photo: P. Niewöhner 2009)

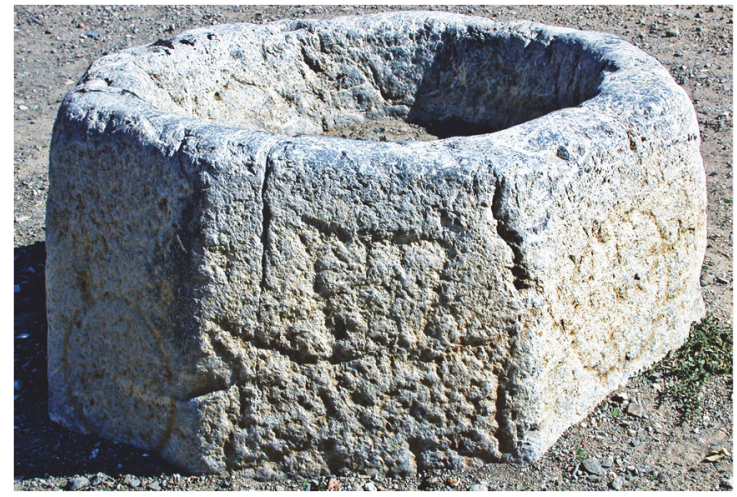

Fig. 16) Octagonal cross stone, half buried in the ground, at Akyurt, previously called Ravl (photo: L. E. Vardar 2005). The front with an incised cross, the two flanking sides each with an incised circle, the five remaining sides blank, the top later hollowed out to serve as mortar for bulgur

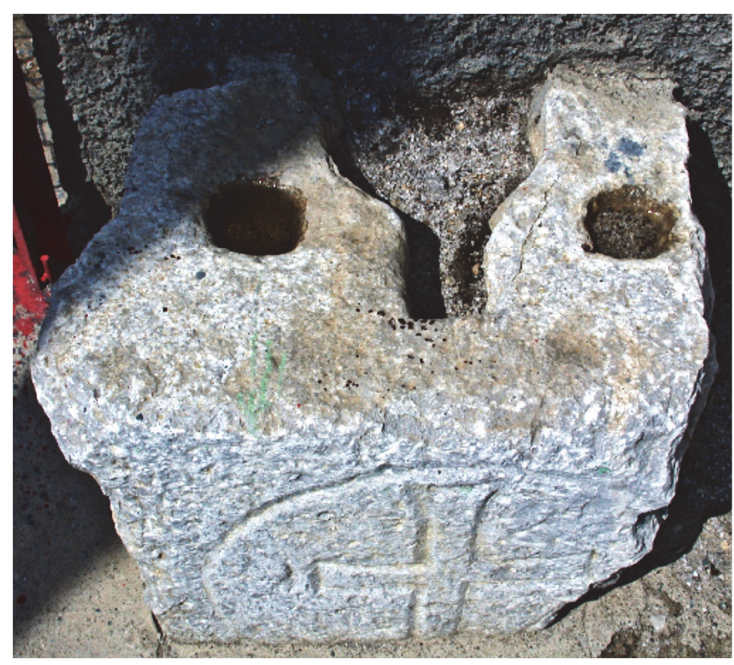

Fig. 18) Rectangular press weight with keyhole-shaped cavity and two (formerly four?) flanking holes on top, reused as cornerstone of a house at Hasanoğlan (photo: $L$. E. Vardar 2004). The front with a cross medallion partly buried and broken at the lower left 


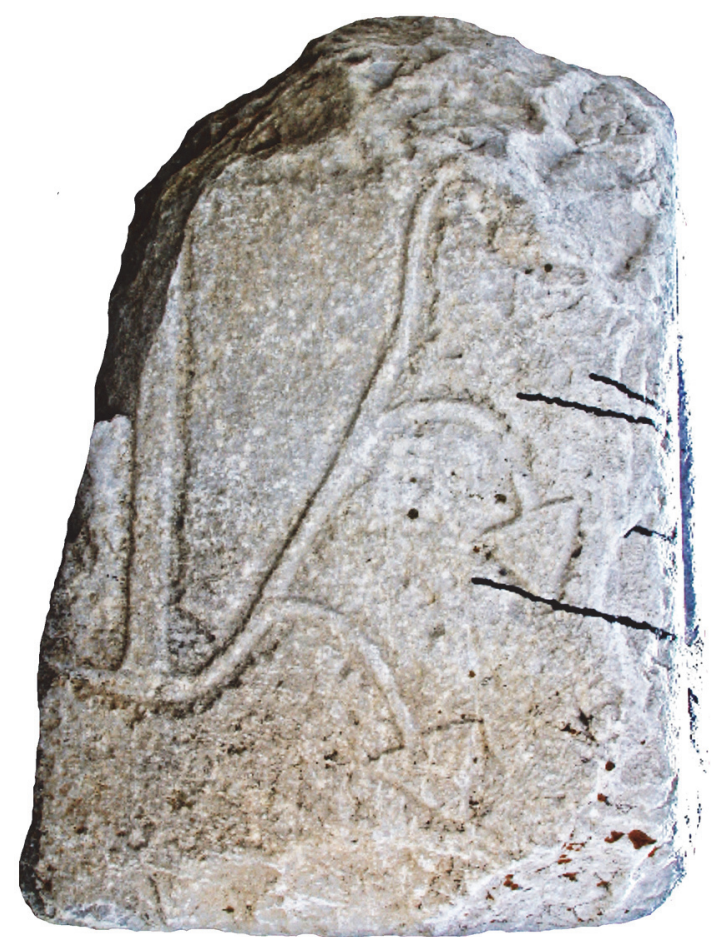

Fig. 19) Rectangular cross stone at Hasanoğlan (photo: L. E. Vardar 2004). Front and back each with a cross and flanking ivy, broken on top, later re-used with the right side up and hollowed out as mortar for bulgur; black oil paint has run down from that side

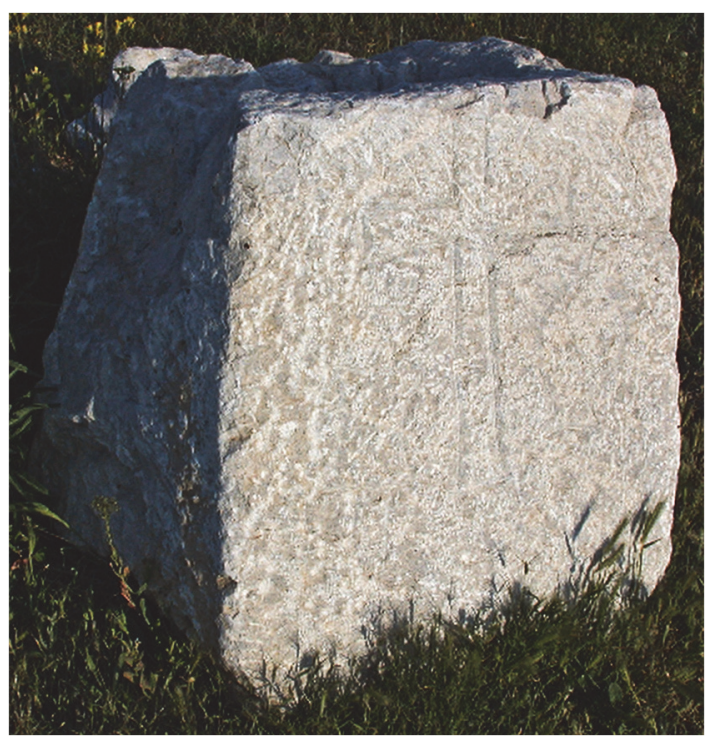

Fig. 21) Rectangular cross stone with slanting sides and cavity on the otherwise broken top, in the municipal park at Elmadăg (photo: L. E. Vardar 2004). An incised cross on the front

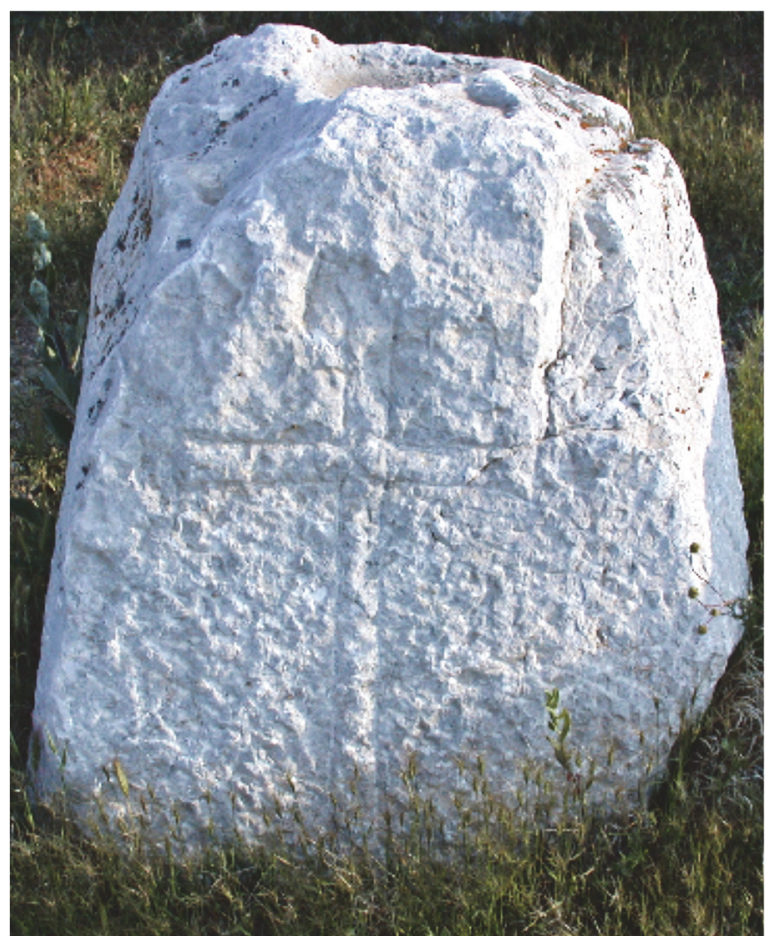

Fig. 20) Rectangular cross stone with slanting sides and cup-shaped cavity on the otherwise broken top, in the municipal park at Elmadağ (photo: L. E. Vardar 2004). Crosses on front and left side, a cross medallion on the right side, the back side broken

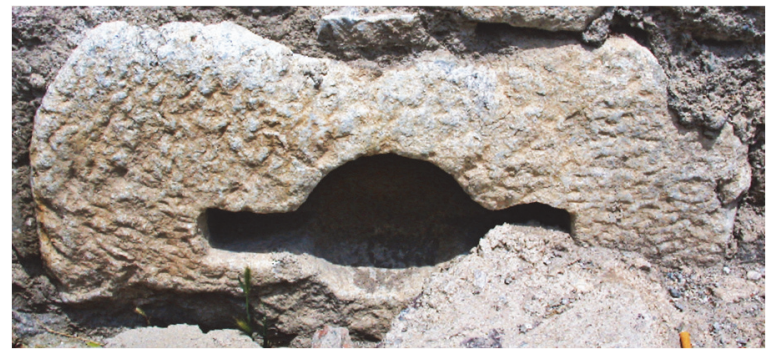

Fig. 22) Rectangular press weight with keyhole-shaped cavity on top, re-used in the wall of the mosque at Gökçeyurt, previously called Nenek (photo: L. E. Vardar 2004) 


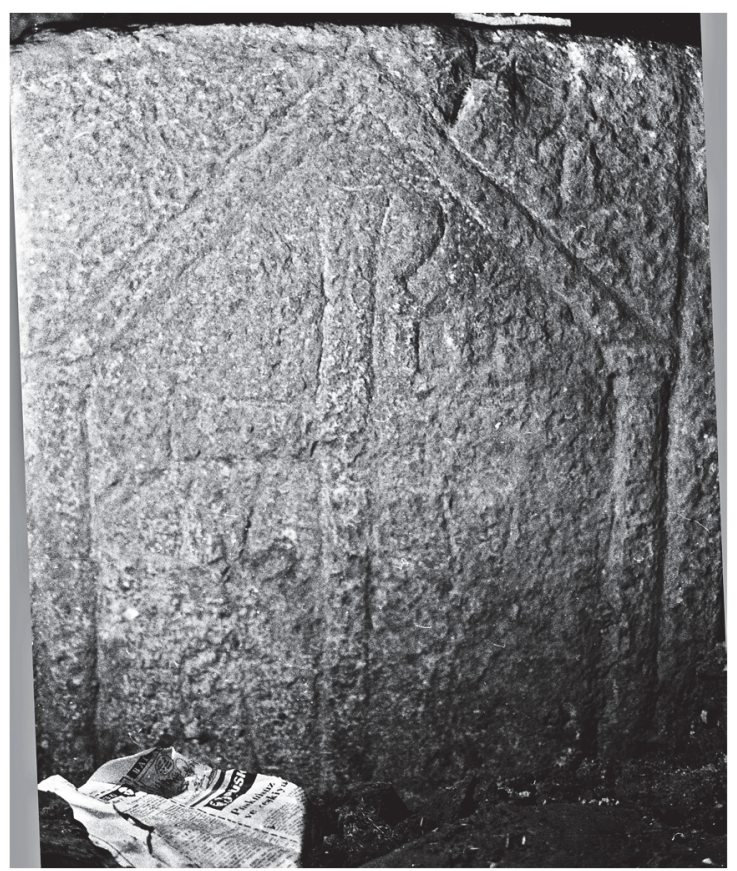

Fig. 23) Rectangular press weight with keyhole-shaped cavity on top, at Elmadağ (photo: S. Mitchell 1971). The front is carved in the shape of an aedicula niche with pilasters (bases and capitals) that support a triangular gable and enclose a large Christogram and two smaller crosses. The right arm of the Christogram has been cut away and partly damaged, and the smaller crosses have been partly erased, probably in the Islamic period. H 101, W 90, D 40
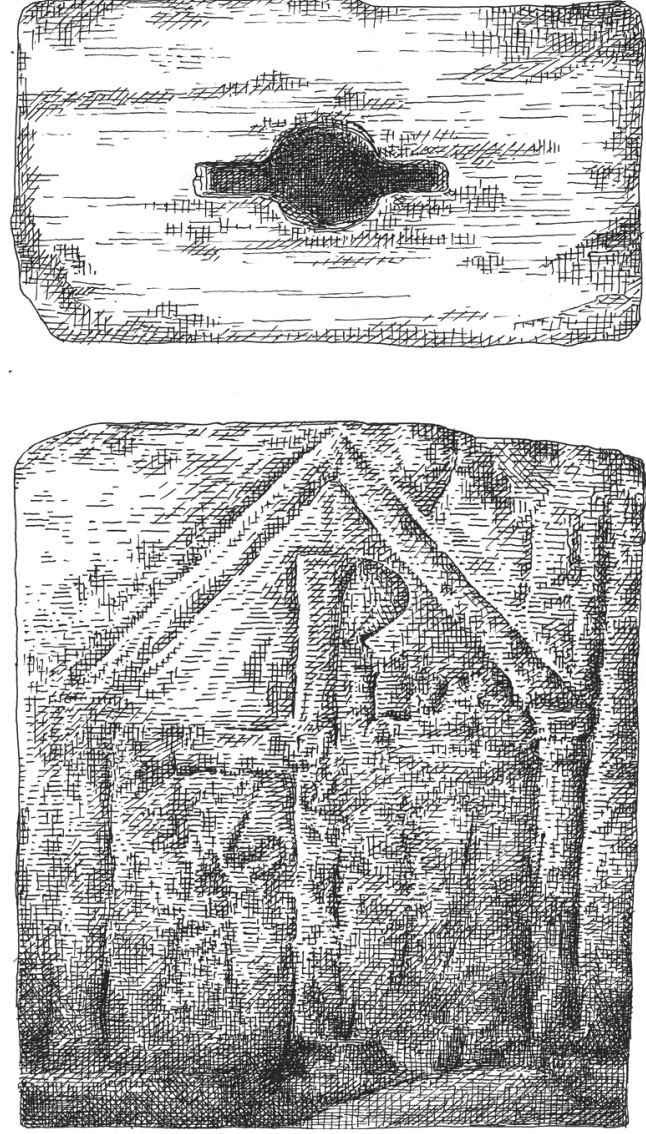

Fig. 24) Drawing of the press weight in the previous figure, showing the front (below) and the top with the keyholeshaped cavity (drawing: Ellen Weise)

\section{Press Weights with Trishagion Inscriptions}

Three press weights from the neighbouring villages of Kutludügün and Elmadağ are inscribed as well as being decorated with crosses and other Christian symbols. All three inscriptions relate to the trishagion, a common Christian prayer and invocation. The most elaborate specimen at Kutludügün (Fig. 25. 26) is similar in size, decoration, and workmanship to the other, uninscribed Christian press weight in the same village (Fig. 9-11). They are both octagonal, have a keyhole-shaped cavity on top, and the three sides that form the front are decorated with large crosses and flanking ivy inside picture panels. The two pieces were undoubtedly made by the same stonemason's workshop, possibly for a complex of several presses.

Another octagonal press weight with a keyhole-shaped cavity on top and with large crosses and flanking ivy on three panelled front sides in the lapidarium by the Roman Baths at Ankara may also belong to this group (Fig. 27). ${ }^{30}$ Evidently, several presses were desirable in a large wineproducing area, as the harvested grapes would not keep and needed to be processed more quickly than was possible with a single press. ${ }^{31}$

\footnotetext{
${ }^{30}$ Inv. 9019: Niewöhner 2020, 328 fig. 1-2.

${ }^{31}$ Cf. above note 29.
} 
The inscription on the press weight at Kutludügün reads:

$$
\begin{aligned}
& \text { "А } ү ı ⿻ \text { 'А } \\
& \text { "A үı⿻ } \\
& \text { K(v́pı)ৎ } \Sigma \alpha \beta a \dot{\omega} \theta \text {. } \\
& \pi \lambda \eta \rho \tilde{\eta} \varsigma \text { oi oủ- }
\end{aligned}
$$

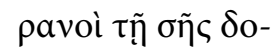

$$
\begin{aligned}
& \xi \tilde{\eta} \cdot \mathrm{K}(\dot{v} \rho \mathrm{\iota}) \varepsilon \beta o i \theta \iota \\
& \Phi \\
& \begin{array}{llll}
\mathrm{Z} & \Omega & \mathrm{H}
\end{array} \\
& \text { C }
\end{aligned}
$$

Holy! Holy! Holy! Lord Sabaoth! The heavens are full of your glory. Lord, give aid!

Life, light.'

$\pi \lambda \eta \rho \tilde{\eta} \varsigma=\pi \lambda \eta \rho \varepsilon \tilde{\varsigma}$; $\sigma \tilde{\eta} \varsigma$ for $\sigma \tilde{\eta}$. This is a familiar case of genitive for dative confusion, and genitives are in fact required here.

The text of the main inscription is a near quotation from the Old Testament, Isaiah 6.3, adapting

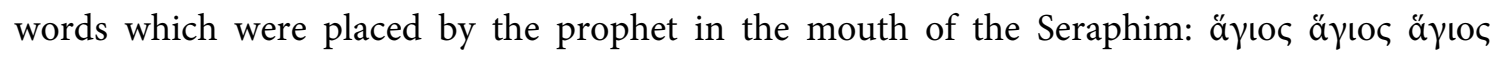

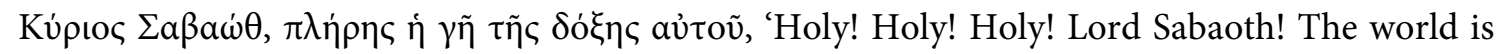
full of his glory!' The New Testament Book of Revelation offers another version, ä $\gamma ı \varsigma$, a $\alpha$ io ,

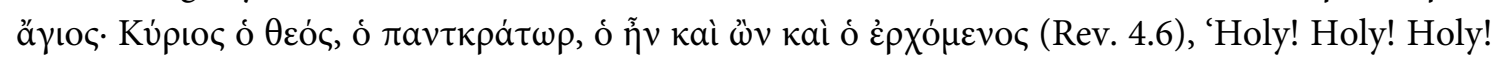
God is the Lord, the Almighty, who was and is and is to come'.

After the Council of Chalcedon in AD 451, the biblical passage, slightly modified from the transmitted text of the Septuagint, became a central part of Church liturgy, the trishagion. Thereafter, the interpretation of the text was an object of dispute between Chalcedonians and Monophysites, but it acquired a fixed place in the liturgy and the Christian epigraphy of Greece, Asia Minor, and the Near East. ${ }^{32}$ The invocation for God's help and protection was incorporated into building inscriptions and epitaphs, and carved on silver and bronze vessels. ${ }^{33}$ It is thus not surprising that it should also appear on a press weight, in an inscription which ends by explicitly invoking God's help with the words $\mathrm{K}(\dot{v} \rho \mathrm{l}) \varepsilon \beta$ ß $\dot{\theta} \theta \varepsilon$.

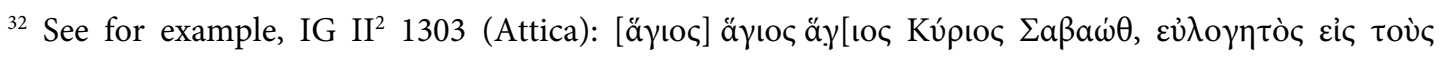

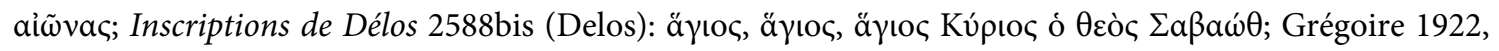

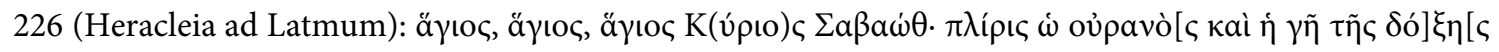

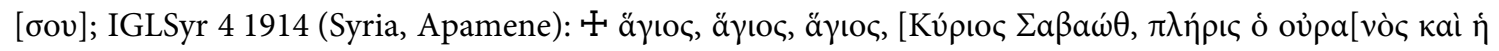

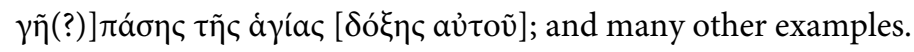

${ }^{33}$ See other occurrences noted by Feissel 2006, 346 (the Sion treasure); 1067 = SEG 44.752 (E. Sicily); 1091 (on a bronze bell); 1106 (on a bronze cross).
} 
The trishagion became familiar to Christians of all classes not through reading the biblical texts, but because of its repeated use in the liturgy, as a prayer for every occasion. As part of the acclamatory culture of late antiquity, it was as ubiquitous as Bismillah irrahman irrhahim in both the spoken and written environment of Islam. The epigraphic evidence demonstrates that it occurred in innumerable contexts of everyday life as well as at the heart of formal liturgy.

The second trishagion inscription is engraved on the tabula ansata of a press weight at the neighbouring village of Elmadağ (Fig. 28). The weight, tabula, and inscription are slightly damaged on the left and partly broken off on the right. The inscription can, however, be read and reconstructed with certainty. The text formed the second element of the spoken prayer of the

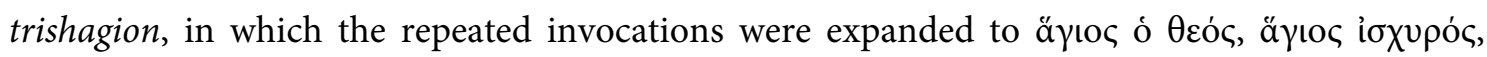
ă $\gamma$ เoৎ à $\theta \dot{\alpha} v a \tau o \varsigma$, 'Holy is god! Holy mighty! Holy immortal! ${ }^{34}$

\title{
A
}

$\mathrm{XY}$ P O C

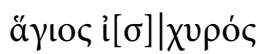

\section{Holy Mighty!}

The third press weight with a trishagion inscription was also found at Elmadağ and displays tabulae ansatae, and the two inscribed weights at Elmadağ are also similar in so far as they are both hexagonal and employ a rounded projection at the top (Fig. 29). None of these features is attested elsewhere in the survey area. As in the case of the two aforesaid weights at Kutludügün (Figs. 9-11.25.26), the similarity of the two hexagonal blocks at Elmadağ suggests that they were made by the same stonemason's workshop, probably for another cluster of presses (but not necessarily by the same workshop which produced the weights at Kutludügün). The second inscribed press at Elmadağ has two inscribed tabulae ansatae, one on the front and one on the next side to the right (Fig. 29). The inscription on the front reads

\author{
EMMA \\ NOYH $\Lambda$

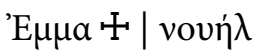

\section{Emmanuel!}

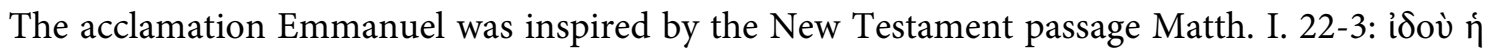

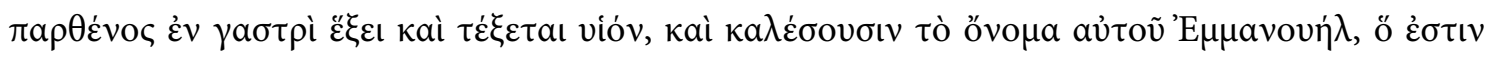
$\mu \varepsilon \theta \varepsilon \rho \mu \eta v \varepsilon v o ́ \mu \varepsilon v o v \mu \varepsilon \theta$ ' $j \mu \tilde{\omega} v$ ó $\theta \varepsilon$ ć, 'See! The virgin shall have a child in her womb and bear a son, and they will call his name Emmanuel, which, being translated, means "god with us"'. Several words from this citation, which hails the virgin birth of Jesus, were often inscribed as an

34 Compare SEG 20. 365 (Tchalenko 1958, appendix II, 28) from northern Syria: ¥ ä

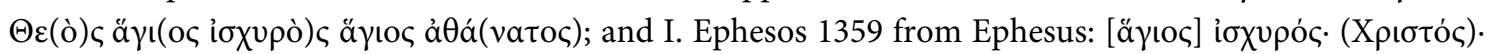

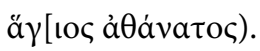




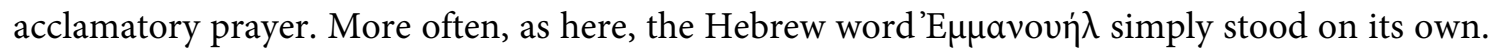
As in our case, several inscribed or painted examples place a cross - another symbol of the crucified Christ - at the centre of the word. ${ }^{35}$ On the inscribed weight at Elmadağ, the Emmanuel prayer is combined with the trishagion on the second tabula ansata, placed on the next side to the right of the hexagonal block (Fig. 29). This tabula ansata is broken on the right side, but can be read and reconstructed with confidence as follows:

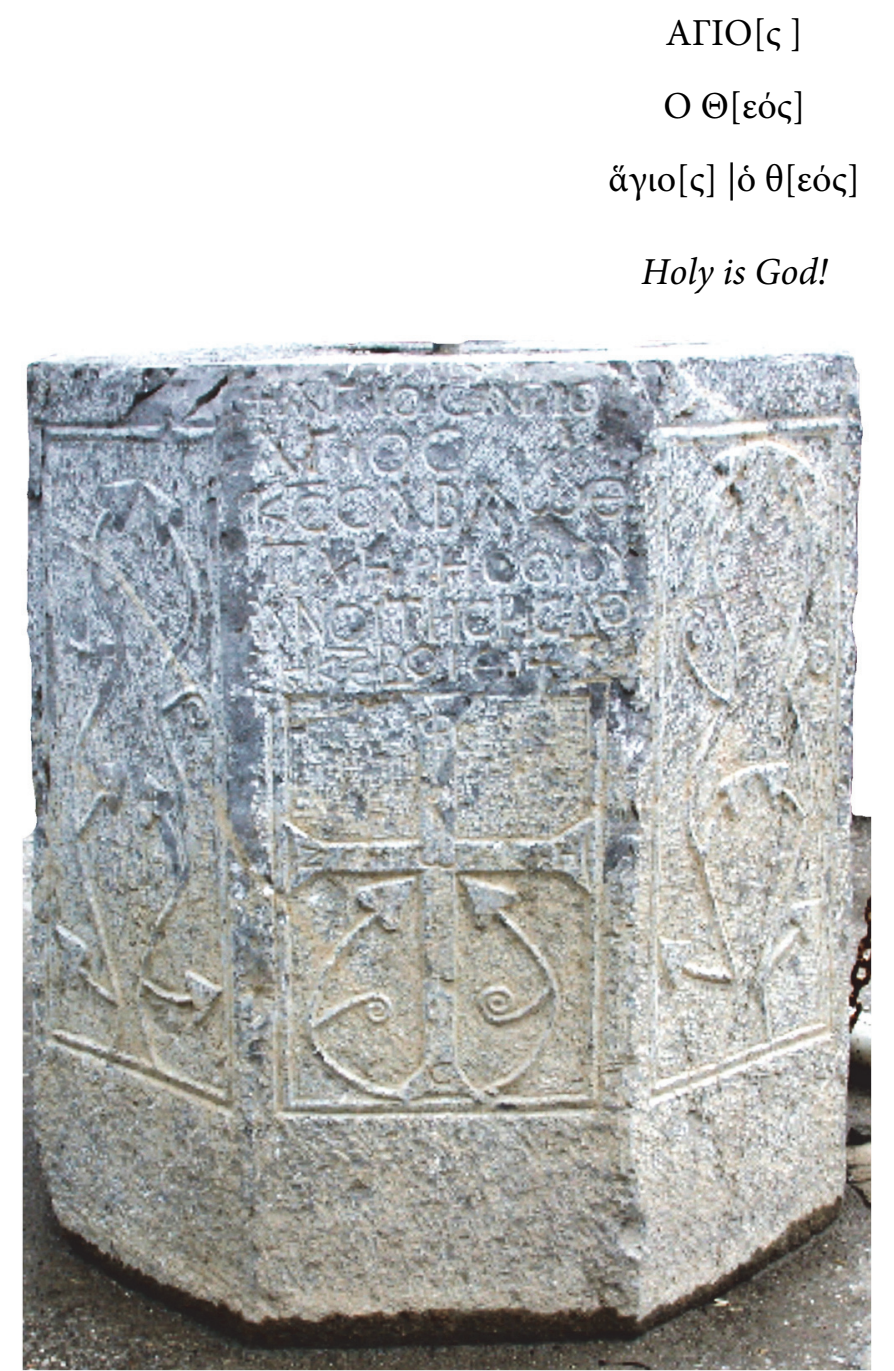

Fig. 25) Octagonal press weight with keyhole-shaped cavity on top, now filled with concrete, retrieved from the graveyard of Kutludüğ̈̈n in 2004, then and 2016 in front of the municipal building (photo: L. E. Vardar 2004). The front has a $\varphi \tilde{\omega} \varsigma \zeta \omega \dot{\eta}^{-}$ cross and flanking ivy inside a picture panel, as well as an inscription on top; the two flanking sides are also panelled and decorated with ivy; the remaining sides are blank. $H$ 100, Ø 91, W of one side 40

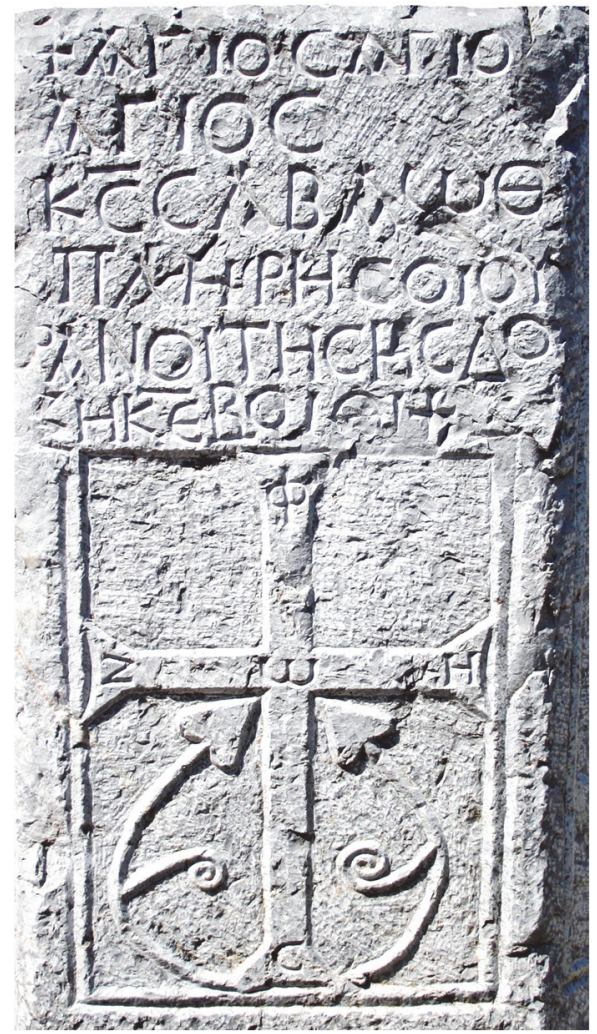

Fig. 26) Detail of the frontal panel and inscription on the octagonal press weight in the previous figure (photo: S. Mitchell 2016)

${ }^{35}$ E.g. at Amphipolis (Serres 1998, 136, 10); on the wall of a Christian tomb at Augusta Traiana in Thrace (SEG 49.872); at Pyli on Cos (Paton - Hicks 1891, 357b); at Anasartha in North Syria (IGLS 2 299), in the Hauran in north Arabia (IGLS 21.5.1 112); and at Synnada in Phrygia (MAMA IV 105). 


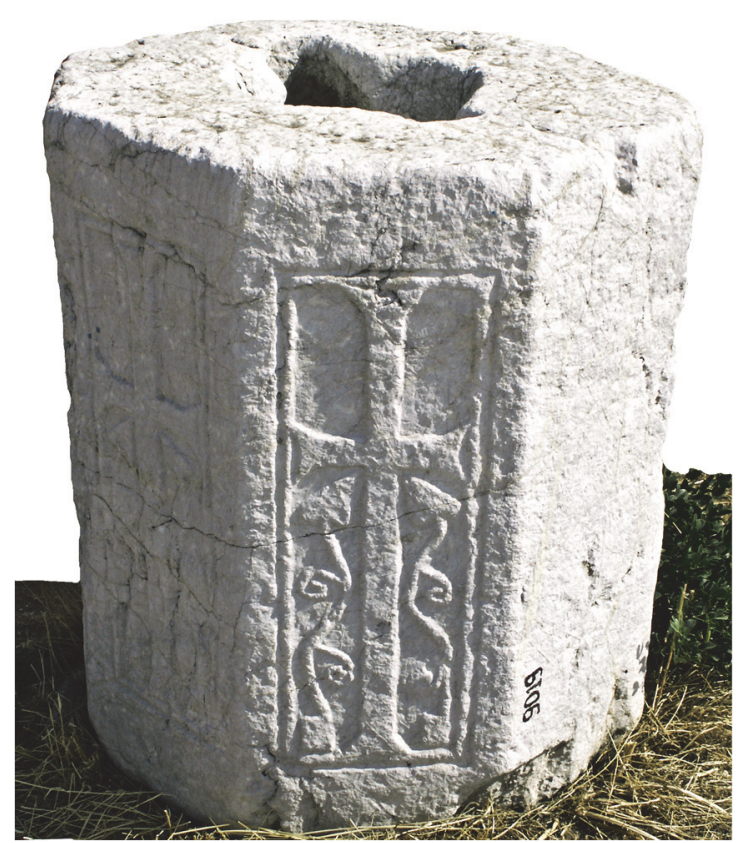

Fig. 27) Octagonal press weight with a keyhole-shaped cavity on top, in the lapidarium by the Roman Baths at Ankara, inv. 9019, but no recorded find spot (photo: J. Kramer). Three front sides (two of which are visible on the left of the photograph) are each decorated with a cross and flanking ivy inside a picture panel

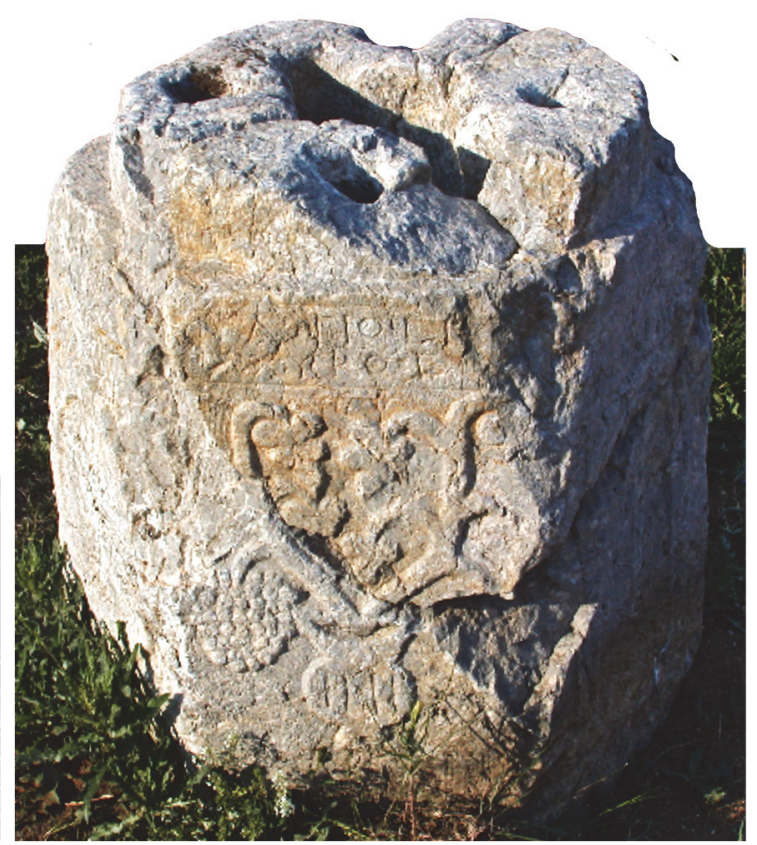

Fig. 28) Hexagonal press weight with keyhole-shaped cavity and four flanking dowel(?) holes sunk into a circular projection at the top, in the municipal park at Elmadăg (photo: L. E. Vardar 2004). The front with vase, vine, and tabula ansata with inscription, the other sides blank

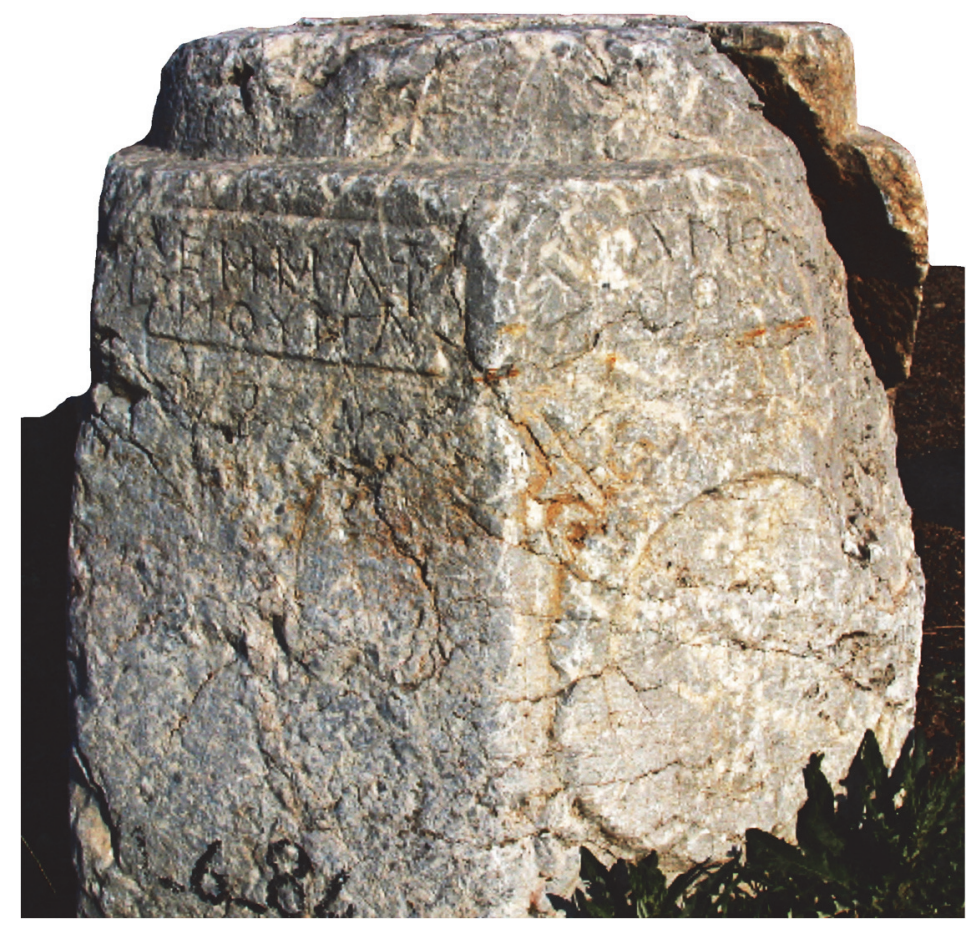

Fig. 29) Hexagonal press weight with keyhole-shaped cavity and four flanking dowel(?) holes set in a circular projection at the top, in the municipal park at Elmadăg, inv. 684 (photo: L. E. Vardar 2004). The front (on the left side of the photograph) with an erased cross and an inscribed tabula ansata, the right side (on the right side of the photograph) with an erased cross inside a medallion that is flanked by corner leaves and topped by an inscribed and broken tabula ansata, the left side (not illustrated) with an erased medallion below and a rose above, the three remaining sides blank 


\section{Two Press Weights outside Kalecik/Malos}

A fourth inscribed press weight, from Kalecik/Malos, has already been published, but was misinterpreted as being an octagonal column base from the church of St Theodotus outside Malos (Fig. 30-33). In 1970, the weight was seen in a cemetery about 500 m northwest of Kalecik castle and north of the stream which runs down towards the Kizll Irmak river, with Kalecik lying to the south. A second weight without inscription was found on the road leading away from the find-spot of the inscribed stone westwards in the direction of Gölköy, and published together with the inscribed one. It is seven-sided, has crosses on three adjacent sides, is $75 \mathrm{~cm}$ high but partly buried, measures $86 \mathrm{~cm}$ across, and has a keyhole-shaped cavity in the top measuring 47 by 23 . Originally, the two press weights will have belonged to a wine production unit outside the town of Malos. ${ }^{36}$

More needs to be said about the inscribed weight on the basis of four photographs taken by its first discoverer, I. W. Macpherson, in the early 1950s (Fig. 30-33). They show the large and heavy stone half sunk into the ground. No doubt Macpherson had cleared the soil round the lower part of the stone to reveal the reliefs and inscriptions. Macpherson's four photographs provide the following readings of the inscription:

On the first two sides of the weight, the start of the first line of text cannot be read on the photograph, but was copied by Macpherson (Fig. 30):

Cross in wreath; large cross, palm to left and plant to right

$\triangle \mathrm{OTE} \mathrm{BO} \mid \mathrm{H} \Theta \mathrm{I}$

| AYTON

|ANTSN

On the second and third sides (Fig. 31):

Cross with palm and plant; cross in wreath above a plant

$\mathrm{H} \Theta \mathrm{I}$

AYTON |

ANTSN|INOYT|

On the fourth and fifth sides (Fig. 32):

Large rosette above cross; large plant

EXN.T|OY@EO

On the sixth and seventh sides (Fig. 33):

Large Latin cross; coiled snake

$\triangle$ OTOY | ҮГІА

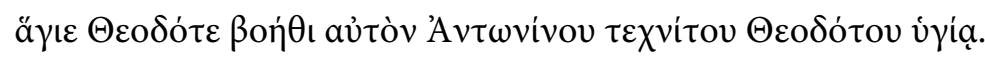

Saint Theodotus, come to their aid, Antoninus the craftsman and Theodotus, with health!

\footnotetext{
${ }^{36}$ RECAM II 212; Mitchell 1982, 99-100. The suggestion that the stone was a column base led Tabbernee 1997, 526 no. 88 to attempt an unconvincing drawn reconstruction of a massive octagonal column or pier.
} 
This version of the text assumes that av่tóv substitutes omicron for omega and should be under-

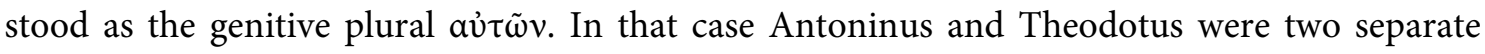
people and the link word $\kappa a i / \kappa \varepsilon ́$ was simply omitted. If avֹ่óv is treated as an accusative object of $\beta$ on $\theta \mathrm{l}$, other interpretations are possible, although the inscription then reverted to the grammat-

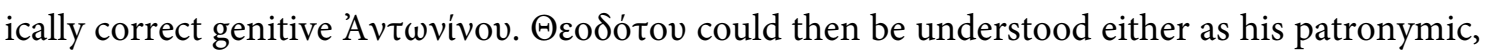
Antoninus, the craftsman, son of Theodotus, or be a compressed allusion to the Church of St Theodotus, Antoninus the craftsman of (the church of St) Theodotus, the saint who is the object of the appeal in the inscription, as suggested by P. Nowakowski. ${ }^{37} \mathrm{~W}$. Tabbernee suggests a further variation, St Theodotus: aid the health of Antonios (sic), artisan, and of Theodotus. ${ }^{38}$ Certainty is not possible. ${ }^{39}$ We should, however, identify Antoninus as the craftsman-engineer (technites) who made the press to which the weight belongs.

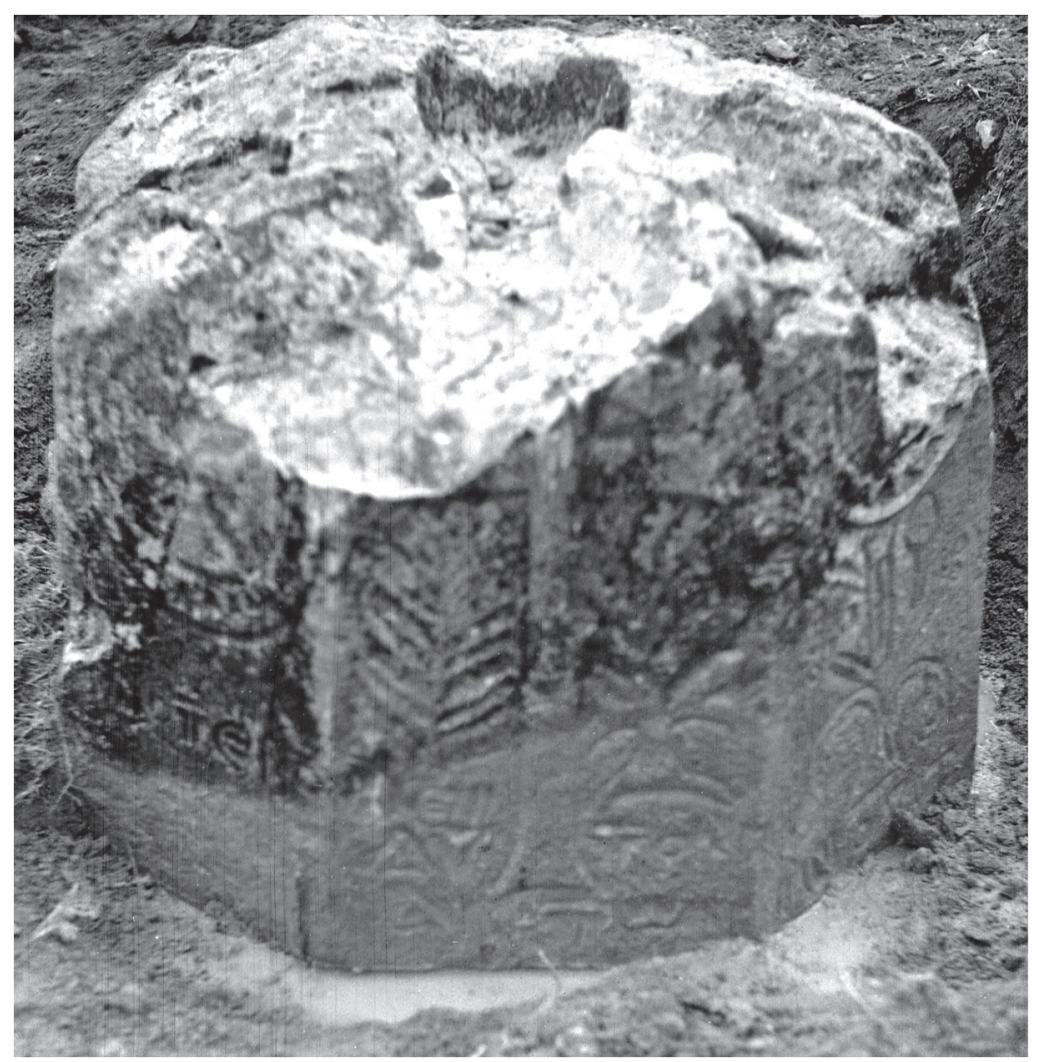

Fig. 30) Octagonal press weight with cavity on broken top, partly buried in the vicinity of Kalecik/Malos (photo: I. W. Macpherson, 1950s). Seven sides are inscribed at the bottom, and this photograph shows the first three. The first side, on the left of the photograph, is decorated with a cross in a wreath, the second side, in the centre, with a large cross and flanking plants, the third, on the right, with a cross in a wreath above a plant. $H 65, \varnothing 80$, letters 4

\footnotetext{
${ }^{37}$ Nowakowski 2018, 498-499 GAL/01/01.

38 Tabbernee 1997,526 no. 88.

${ }^{39}$ See U. Huttner in ICG 2382: 'Die Grammatik ist nicht ganz klar'.
} 


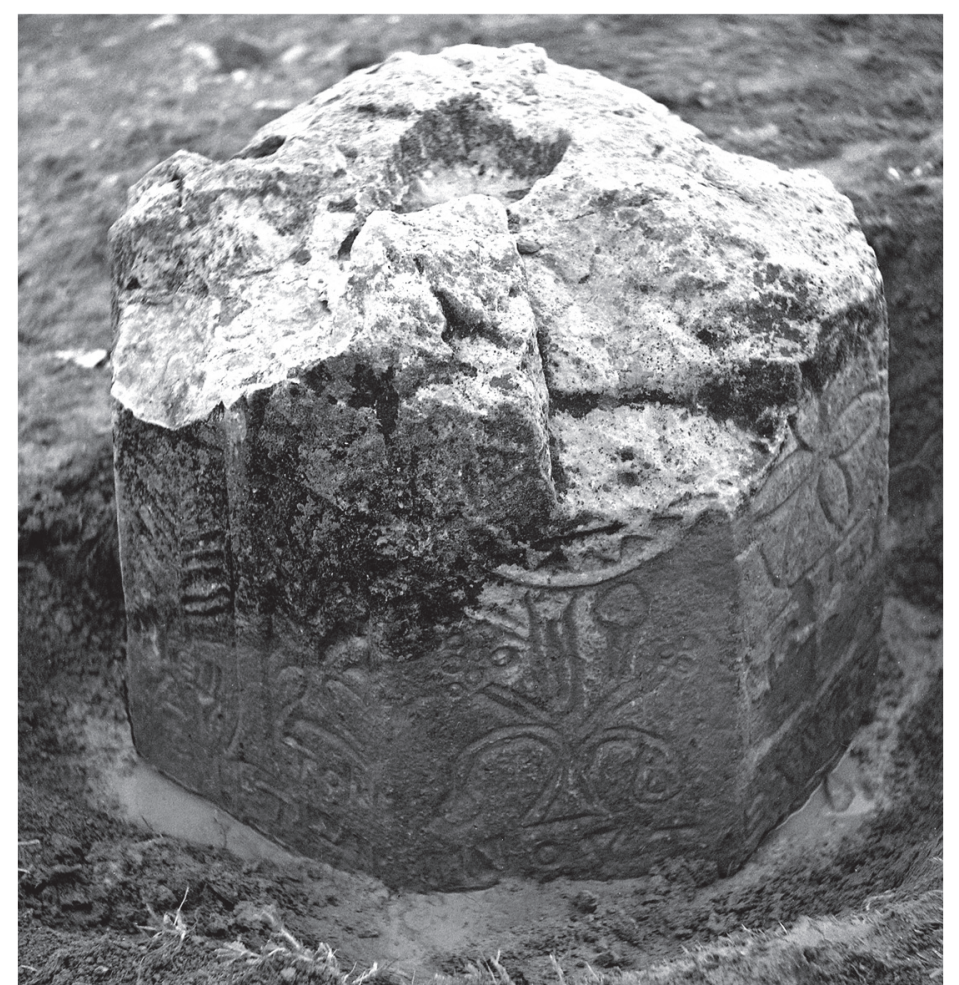

Fig. 31) Sides two to four of the octagonal press weight in the previous figure (photo: I. W. Macpherson, 1950s). The second side, on the left of the photograph, is decorated with a large cross and flanking plants, the third side, in the centre, with a cross in a wreath above a plant, and the fourth side, on the right, with a rose above a small cross and a flanking pair of birds

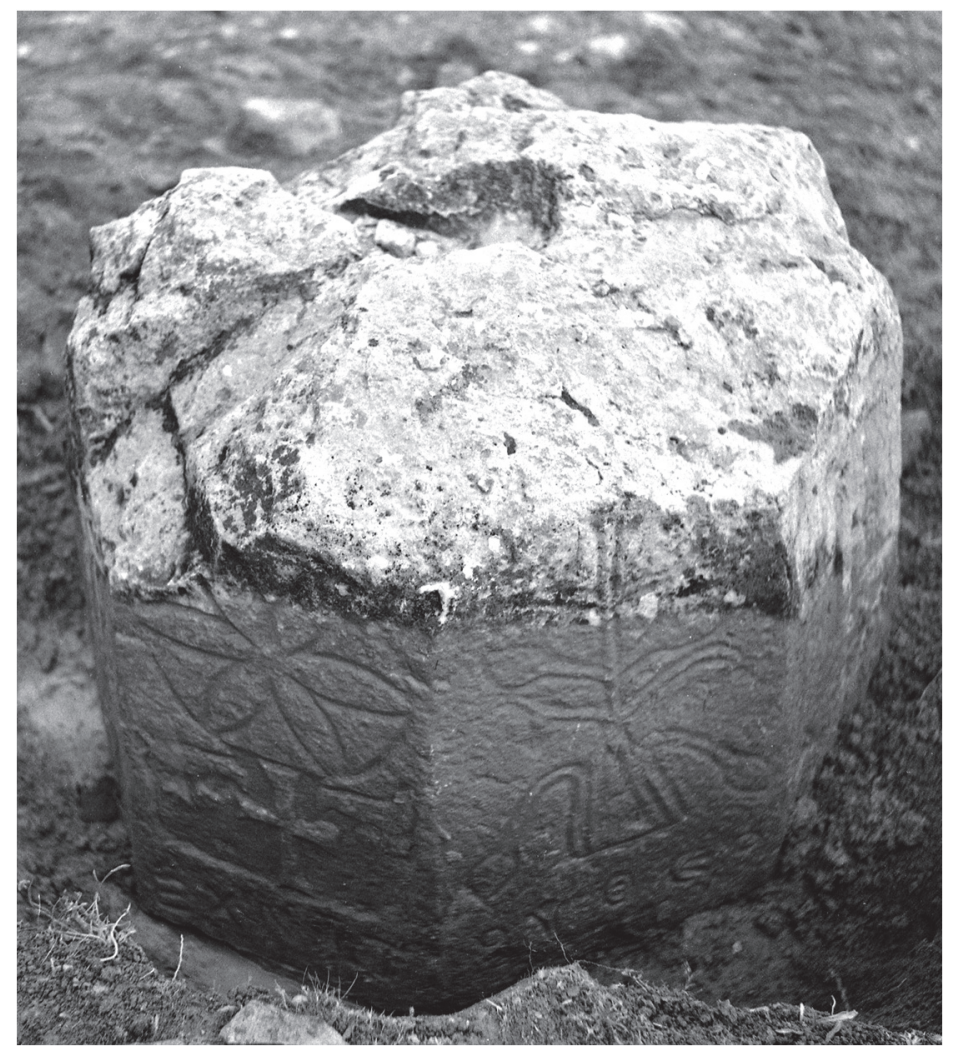

Fig. 32) Sides four and five of the octagonal press weight in the previous figures (photo: I. W. Macpherson, 1950s). The fourth side, on the left of the photograph, is decorated with a rose above a small cross and a flanking pair of birds, the fifth side, on the right, with a large plant 


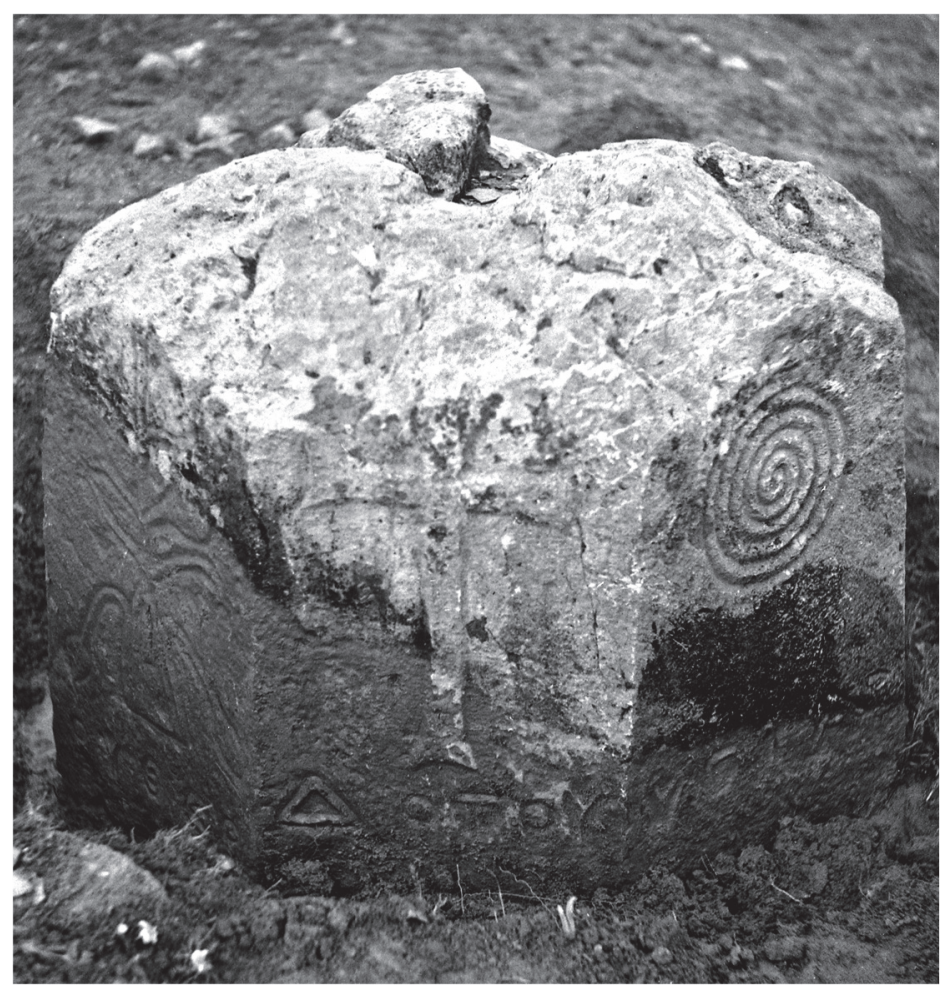

Fig. 33) Sides five to seven of the octagonal press weight in the previous figures (photo: I. W. Macpherson, 1950s). The fifth side, on the left of the photograph, is decorated with a large plant, the sixth side, in the centre, with a large cross, and the seventh side, on the right, with a coiled snake

\section{Healing, Health, and the Symbol of the Coiled Snake at Kalecik/Malos}

The image of the coiled snake above the word vyia on the seventh side of the inscribed press weight from Kalecik/Malos (Fig. 33) is surely witness to a survival of the pagan belief in the snake as a symbol of healing. The image of a snake was associated, and sometimes fully identified, with the god Asklepios. Tabbernee speculates that the choice of image might have represented the serpent which tempted Eve, but rightly reverts to a better explanation: ${ }^{40}$ 'The serpentine spiral was of course a universal symbol of healing and hence, irrespective of any intended biblical allusions, was carved above the word vyía in this appeal for health.' To illustrate this, a small votive inscription from the Afyon region in Phrygia, photographed by Macpherson, shows

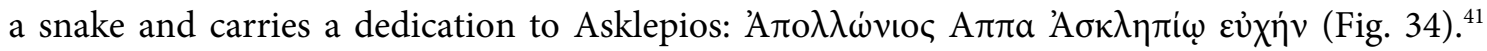
Several examples of votive texts dedicated to Asklepios or other healing divinities simply depicting a snake have been recorded in north-western Asia Minor and the south-eastern Balkan regions, the main centre of healing snake cults both in antiquity and into modern times.

\footnotetext{
40 Tabbernee 1997, 528.
}

${ }^{41}$ This small dedication was moved from Afyon Museum (inv. no. 1736) to Bodrum Museum (inv. no. 3.8.95) for an exhibition in 1995 and remained on display in the Yılanlı Kule. It was published by Akyürek-Şahin 2004, 141 no. 2 with the reported provenance Kale Köyü, Afyon. Kale Köyü is east of Afyon roughly half-way between Iscehisar (Docimium) and Bolvadin (Polybotus). 


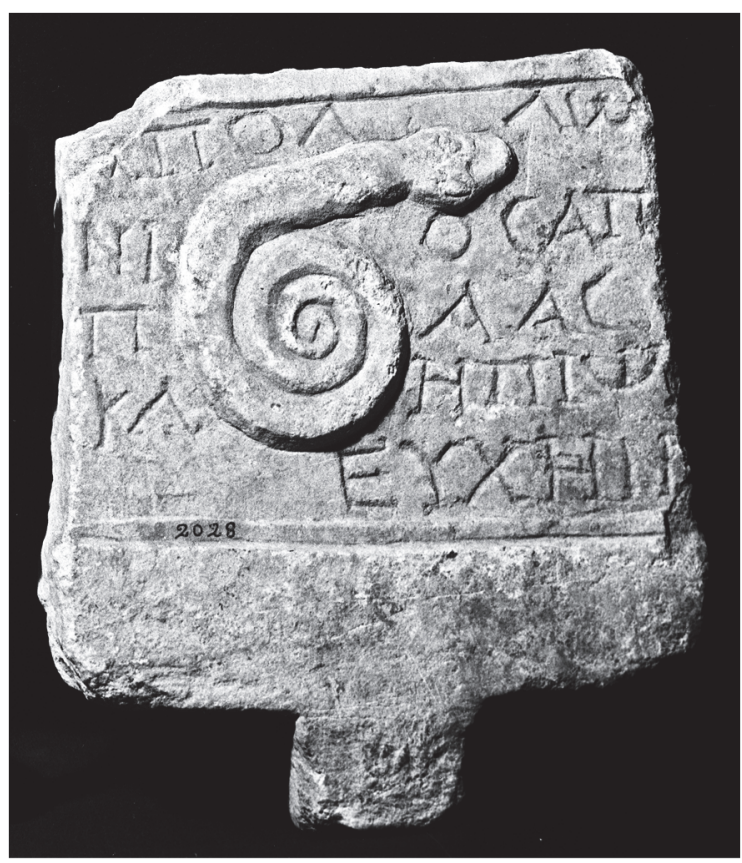

Fig. 34) Small votive stele from the Afyon region in Phrygia, Afyon Museum inv. 1736 (photo: I. W. Macpherson c. 195154). A coiled snake is flanked by a dedication to Asklepios. H 17.5, W 17,5; D 4,5; letters 1,5-1,8.

Remarkably, a large altar with a circular top above plain mouldings and with a large snake on the front was seen by Mitchell in 1970 at Kalecik itself (Fig. 35). A worn inscription is to be found on the pediment moulding at the top of the right face (Fig. 36). The text, in careless lettering, seems to have been added almost as an afterthought to the main design of the altar.

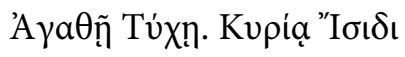

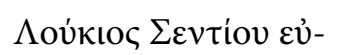

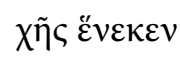

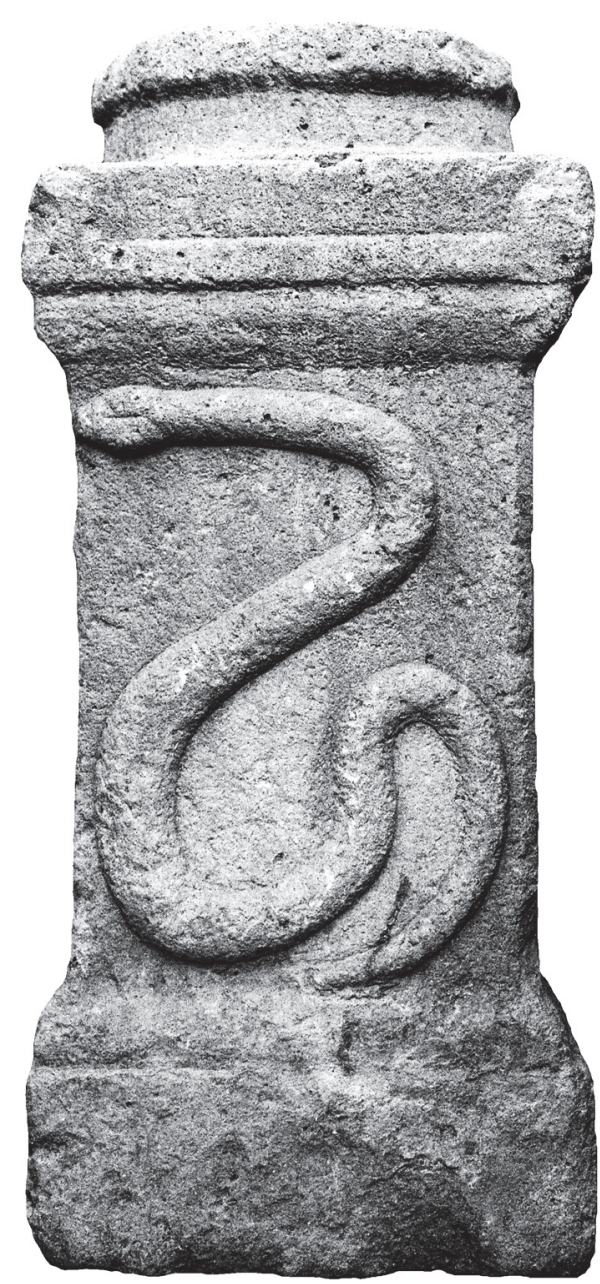

Fig. 35) Large altar with circular top at Kalecik (photo: S. Mitchell 1970). Carved with a large snake and with an inscription on the mouldings of the right side. H. 102, W. 46, D. 46

With Good Fortune! Lucius son of Sentius for the Mistress Isis, in fulfilment of a vow.

1: barely legible, but parts of all the letters can be seen in fig. 36. 2: NT in ligature; 3 : The sigma is cut in 4-barred form and rotated on its side, so that it appears like a ligatured mu between eta and epsilon.

The provenance and publication history of this text present some problems. Apparently, the first person to see the altar was I. W. Macpherson, who included it in his 1958 Cambridge PhD thesis, with a faulty reading in the first line. He wrote that he had copied the stone in the village of Ahmedadil, fifteen kilometres west of Kalecik, and that it had been carried there from an ancient site two miles to the northeast of the village. Mitchell, who saw and copied the same text in Kal- 
ecik itself, republished it as coming from Ahmedadil, based on Macpherson's note. ${ }^{42}$ The Isis sanctuary should accordingly be located at the site near Ahmedadil.

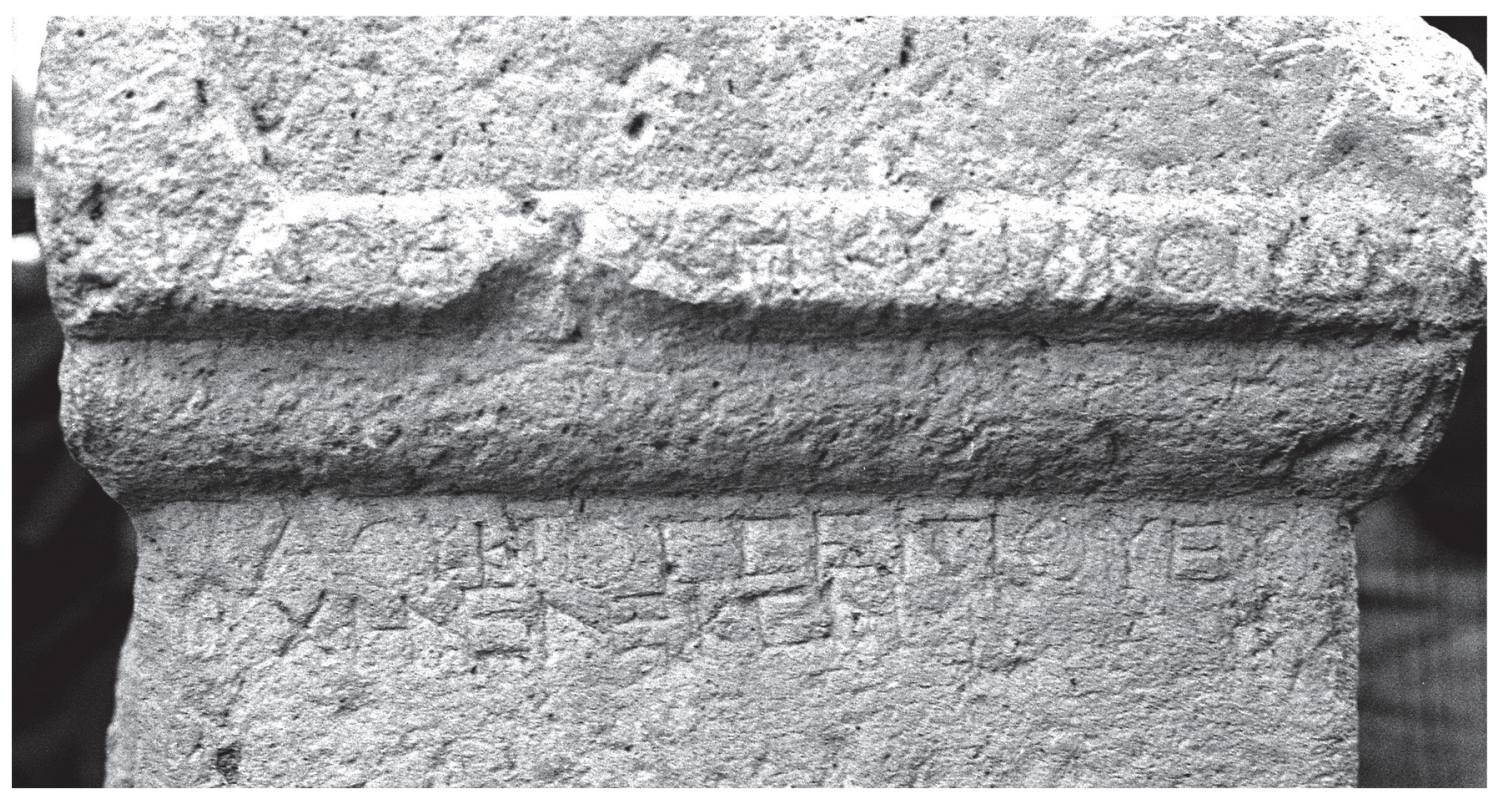

Fig. 36) Detail of the altar in the previous figure, showing the pediment moulding and the top of the right face with a worn inscription (photo: S. Mitchell 1970). Letters 2-2,5

There is, however, a possibility that the monument in fact comes from Kalecik. The English traveller W. H. Hamilton provided a valuable account of antiquities which he saw at Kalecik in 1836, including the press weights that have been discussed above: "In the Armenian burialground also are many large stones evidently derived from ancient buildings, some of them a remarkable shape, being octagonal and tapering slightly upwards, like frusta of unfinished columns, with holes on the top as if for letting in other stones. They may have been sepulchral cippi used in early Christian times. The sides of some were slightly ornamented, and on one were a few words; others had long inscriptions" ${ }^{43}$ Five inscriptions from Kalecik were published in the appendix to Hamilton's second volume, including a Greek epitaph and a milestone. ${ }^{44}$ In addition, Hamilton recorded three other fragments 'in the acropolis' at Kalecik, which have subsequently been included in various corpus collections. ${ }^{45}$ Two of these, nos. 96 and 97, read, respectively, ҮГІА and АГІЕC, the last and first words of the Theodotus press weight inscription. Hamilton's report of slightly tapering octagonal stones with holes in the top indicates that he

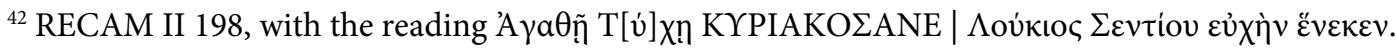

${ }^{43}$ Hamilton 1842, 412-413. Hamilton inserts a misleading footnote here to inscriptions nos. 100 and 101. However, these are texts which he recorded at the village of Akçataş, northwest of Kalecik, and that were subsequently republished as RECAM II 202 and 203.

${ }^{44}$ No. 98 = RECAM II 209, a funerary inscription, set up by a man with the Celtic name Catomarus in AD 165; no. 99 = CIL III 310; D. H. French, RRMAM III. 2, 33[B], the thirty-fifth milestone from Ancyra, set up by the Hadrianic governor, A. Larcius Macedo.

${ }^{45}$ Hamilton 1842, I, 412 ('in the gateway of the lower or outer wall were a few fragments of ancient sepulchral monuments and of inscriptions almost illegible') and II, 416 nos. 95-97 ('fragments in the acropolis'). CIG III 4100 and RECAM II 210, reproduce Hamilton's copies without explanation of the texts. 
had seen these weights, and nos. 96 and 97 are surely an incomplete copy of the inscription discussed above. No. 95 is presented in two lines: ANY . AI |IC . I $\Delta$ I. Ladislav Vidman in his 1969 corpus of the inscriptions for the Egyptian divinities, proposed reading the second line as"I $\sigma \iota \delta$,

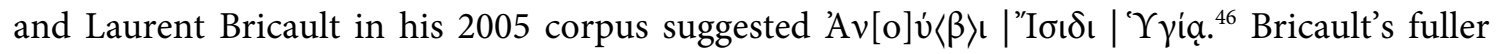
proposal is not supported by any convincing parallels, but the restoration of Isis's name is persuasive. We cannot perhaps rule out that the 1836 record is in fact an imperfect rendering of the

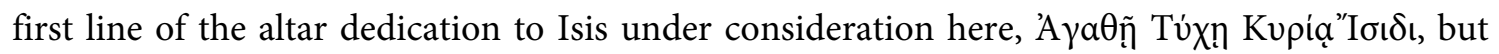
Hamilton's publication divides the words between two lines, and we would have to suppose that Macpherson (usually extremely reliable) made a mistaken report of the inscription's find-spot. ${ }^{47}$ It is better to conclude, therefore, that there were two Isis dedications from the Kalecik area, the altar presented above and the fragment copied by Hamilton.

A $y a \theta \underline{n}$ Túxn at the start flags that the altar with the snake relief is a votive, not a funerary text, comparable with other dedications to the Egyptian deities in Roman Anatolia, ${ }^{48}$ and the deity addressed was the Egyptian goddess Isis, widely popular in the Roman world in the second century, although little attested in central and eastern Asia Minor. Other votives for her are recorded at Ancyra, where there was an important temple for the companion male cult of Sarapis, and at Pompeiopolis in Paphlagonia. ${ }^{49}$ Isis was revered as a goddess of well-being and healing, among many other powers, and serpents were associated with her cult. Sentius was a popular name in the area. ${ }^{50}$ It was etymologically connected to the Celtic form Sentamos, which is also attested on inscriptions in the immediate neighbourhood. ${ }^{51}$

The Life of St Theodotus of Ancyra, which contains detailed information about the natural setting as well as the historical environment of Galatia in the fourth century, presents a remarkably vivid picture of the town of Malos as a delightful oasis of meadows and flowers as well as the fruits of cultivation, which were enjoyed by the saint himself and his companions when they gathered to restore themselves after destroying a pagan sanctuary of Artemis. ${ }^{52}$ This encomium of the small town and the beauties of nature to be found there have been echoed by all modern travellers to Kalecik, which presents a green and fertile contrast to much of the surrounding

\footnotetext{
${ }^{46}$ Vidman 1969, 337; Bricault 2005, 480, 311/0201.

${ }^{47}$ Hamilton's itinerary did not take him to Ahmetadil, and so he cannot have copied the fragment
} there.

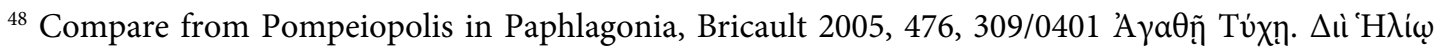

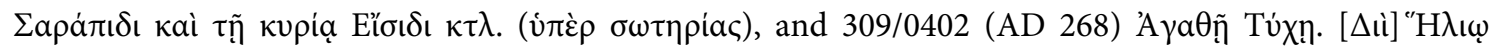

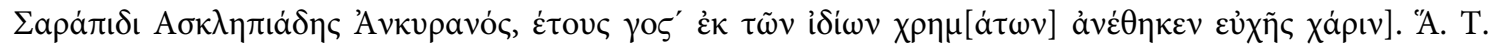
regularly introduced votive texts in Galatia, see RECAM II 191 (Kizılcahamam, Zeus Souolibrogenos), 418 (Tavium, Theos Hypsistos), and elsewhere.

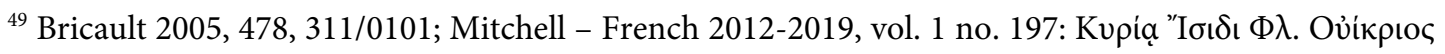

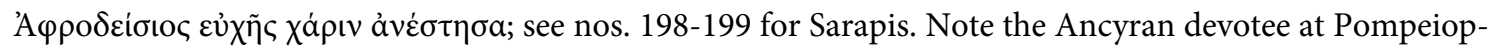
olis, cited in n. 48.

${ }^{50}$ Cf. RECAM II 193.

${ }^{51}$ RECAM II 201 and twice in RECAM II 206.

${ }^{52}$ Life of St Theodotus 10-11. 
region, ${ }^{53}$ and these virtues were further enhanced by its reputation as a centre of wine production. In antiquity it would have received many visitors in search of health and recreation from Ancyra itself and from further afield. The healing snake which appears on the altar to the Egyptian goddess Isis, who doubtless was worshipped in a modest shrine here, and on the early Byz antine press weight, invoking good health and the protection of Malos's patron saint Theodotus, himself a wine-dealer, provide good reasons for regarding Kalecik/Malos in the Roman and early Byzantine period, as the equivalent of a modern Kurort.

\section{Another Christian Inscription from Kalecik/Malos}

Another Christian inscription, copied beside a fountain at Kalecik in the late nineteenth century and now in the lapidarium by the Roman baths at Ankara, which refers to the building of a martyrium, has been connected to the church of St Theodotus outside Malos, and published with

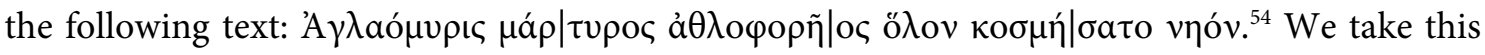
opportunity to publish the first photograph of the inscription and to revise the readings, as well as to examine its connection to the church of St Theodotus outside Malos (Fig. 37).

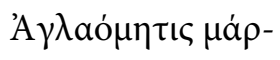

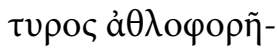

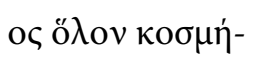

$$
\begin{aligned}
& \text { бато vฤóvษ }
\end{aligned}
$$

Aglaometis adorned the whole church of the trial-enduring martyr.

Previous editions have adopted the incorrect reading of the text's discoverer, Legrand, 'A $\gamma \lambda$ aó

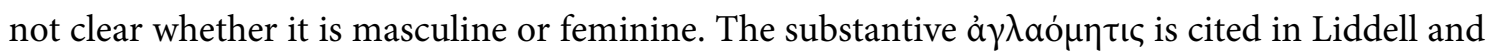
Scott from Tryphiodoros, The Capture of Ilion, $183\left(3^{\text {rd }} / 4^{\text {th }}\right.$ cent.) with a male, and Proclus, Hymns V, 10 ( $5^{\text {th }}$ cent.) with a female complement, to mean 'a person of rare wisdom'. The adjective à $\gamma \lambda \alpha o \mu \eta \dot{\tau} \tau\rceil$ is used in a poem of seven elegiac couplets inscribed at Phrygian Hierapolis to describe a prominent Roman official, Fl. Magnus, vicarius Asiae around the middle of the fourth century. ${ }^{55}$ Aglaometis might have been used at Kalecik as the descriptive sobriquet of a benefactor, whose conventional name appeared on another part of the building. Although it stands extra metrum, rhythmically the word forms the last two feet of a dactylic verse, and thus leads smoothly into the complete verse that follows.

For the use of such a descriptive tag in this region, to enhance a donor's name, we can compare the early fifth-century donor inscriptions at Ancyra, which refer to the city benefactor Ioannes,

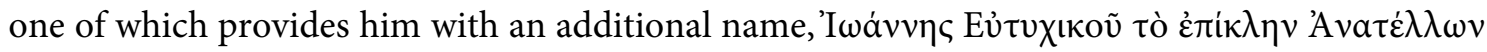
('the restorer'), while the other, a verse text, ends with the acclamation, aứı 'I

\footnotetext{
${ }^{53}$ Mitchell 1982, 97-98 with references.

${ }^{54}$ Legrand 1897, 101 no.22; RECAM II 211; Steinepigramme 3, 142: 15/02/10; Tabbernee 1997, 532 no. 89; Nowakowski 2018, 499-500 GAL/01/02; ICG 2381.

${ }^{55}$ Steinepigramme 1, 266-268: 01/12/06 (ICG 927).
} 


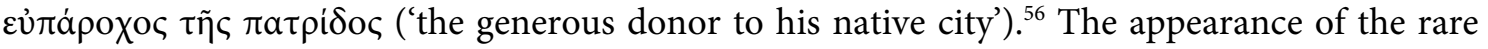
word $\dot{\alpha} \gamma \lambda \propto o ́ \mu \eta \tau \iota \varsigma$ in a verse text attests a high level of culture, and the fine quality of the inscription implies that it relates to a church building of considerable architectural pretensions. It is a reasonable conjecture that the text refers to the most important martyr of Malos, St Theodotus, whose church was erected, according to the life, a short distance outside the town, but this is not certain. The Life of Theodotus itself provides evidence for another martyr's shrine in the place, dedicated to Valens, otherwise unknown, and he could also be the object of the dedication. ${ }^{57}$ In addition, remains of a church, including a font, also existed inside Kalecik/Malos. ${ }^{58}$

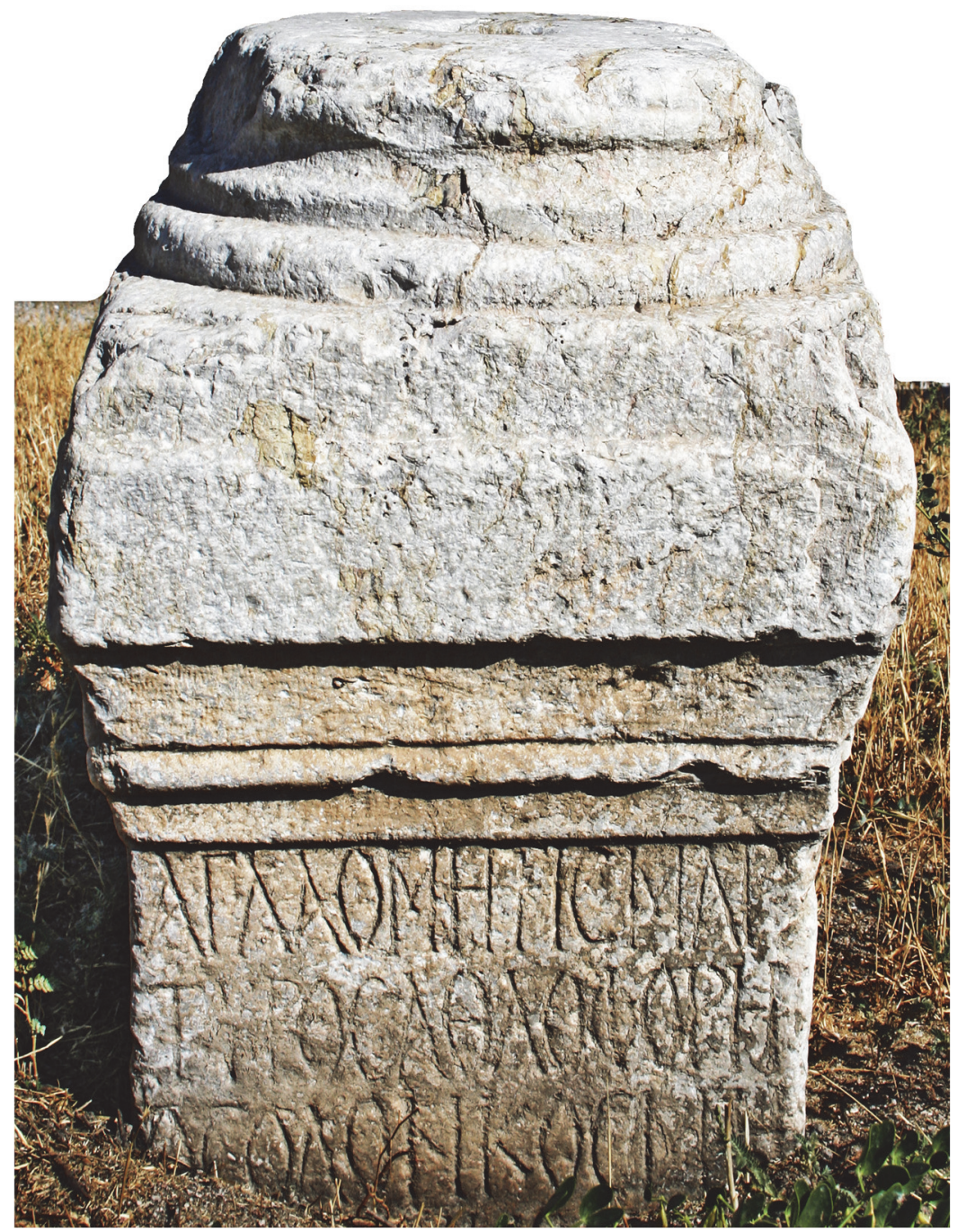

Fig. 37) Tall pediment and column base from Kalecik, now (since 1995?) in the lapidarium by the Roman Baths at Ankara, inv. 113.494 .99 (photo: S. Mitchell). A dowel hole in the centre of the column base; the shaft broken below the inscription; a slot for a barrier slab (?) was cut through the upper mouldings at the left-hand side. H. 77, W. 50 (shaft 41), D. 57, Ø 43, letters 6,5. Slender elegant lettering with some apices; alpha with slanting cross bar; rho with small semi-circle, doubtless of the early fifth century

\footnotetext{
${ }^{56}$ Mitchell - French 2012-2019, vol. 1 nos. 334-335.

${ }^{57}$ Life of St Theodotus 10.

${ }^{58}$ Mitchell 1982, 99 with pl. XXVa.
} 


\section{The Press Weights outside Kalecik and St Theodotus outside Malos}

How do the press weights and in particular the one that invokes St Theodotus relate to the saint's church outside Malos? The saint's Life informs us that Theodotus was a shop-owner and a wine dealer who became a martyr of the persecution of Maximinus Daia. One of Theodotus' heroic achievements had been to recover the remains of another martyred Christian from the waters of the river Halys and bring them to a vantage point (бкоті $\alpha$ ), which was about two stades (ca. 400 metres) from the settlement of Malos, with an eastward view from which the river was visible. This precisely describes the location where the inscribed press weight was found, about half a kilometre from Kalecik/Malos, with an uninterrupted sight of the Kizıl Irmak river.

In a doubtless fictitious scene, the life tells how Theodotus then invited the village priest, Fronto, to join him at the spot for an al fresco meal, explaining that this should be the spot where a martyr's remains should be buried and commemorated. ${ }^{59}$ At the conclusion of the life, the narrator tells how Theodotus's remains were recovered by the priest Fronto: He had put an excellent old Malos vintage to good use, causing the handful of soldiers guarding the saint's body to fall into an unconscious stupor, and brought the saint's remains to the very spot where the picnickers had gathered. This became the site of the martyr's church, ${ }^{60}$ and it is tempting to relate at least the inscribed press weight (Figs. 30-33) to the martyrium.

However, whilst both the eight-sided press weight with the inscriptions and the uninscribed seven-sided example were evidently found near the martyr's church, the evidence of the Christian inscription and symbols are not proof that the presses were church property. Appeals for protection to god and his saints (Kúpı ßoj́ $\theta \varepsilon \mathrm{s}$ ), or prayers such as the trishagion on the other inscribed press weights (Figs. 25-29) were almost ubiquitous in the early Byzantine world, and written examples were carved or painted on small objects of private or devotional use, in houses, on public buildings, on gravestones, or on rock faces overlooking rural properties. They attest the widespread Christian devotion of the population, and this is probably the best interpretation of all the Christian symbols that appear on press weights. All important aspects of life and society came under the protection of the Christian God.

\section{Conclusions}

The cluster of highly decorative press weights in the survey area stands out, even by central Anatolian standards. A smaller group of decorative weights has been recorded near Çorum, in the north-eastern extremity of Galatia, but those weights are less elaborate and bear no inscriptions. ${ }^{61}$ The survey area east of Ankara had a distinctive artistic profile that would seem to reflect an exceptionally fertile and wholesome environment, with an ancient tradition of wine making, and which was probably combined with a reputation for healing and well-being. The vines at Kalecik/Malos were famous in antiquity and remain important today, producing a high quality

\footnotetext{
${ }^{59}$ Life of St Theodotus 10.

${ }^{60}$ Life of St Theodotus 23-25.

${ }^{61}$ Niewöhner 2017, 499 fig. XIII-1 - XIII-3; Niewöhner 2020, 329-330 fig. 3-5 and 8. Cf. Keskin 2013.
} 
red wine made from the Kalecik Karası grape variety. ${ }^{62}$ The local populations derived much of their income from wine production, which was marketed in the provincial capital Ancyra not only by the charismatic, if semi-legendary, figure of St Theodotus, but by generations of his followers in the thriving villages which lay between the city and the river Halys.

The decorated press weights appear to have been produced by various rural stonemason's workshops. Two pairs at Kutludüğün (Figs. 9-11. 25. 26) and at Elmadağ (Figs. 28. 29) as well as the inscribed weight from Kalecik/Malos with a dedication to St Theodotus of Malos (Figs. 30-33) confirm that, as a rule, the pieces were not displaced in modern times. Their distribution across the various contemporary Turkish settlements seems to reflect the Byzantine situation. ${ }^{63}$ Moreover, whilst each pair of weights looks alike, the differences in make and decoration between the pairs as well as among the many single pieces suggest that there were several different stonemason's workshops, probably indicating some chronological development as well as stylistic variation. However, the finds from the survey area also display common features like the keyholeshaped cavities (rather than dovetailed sockets on the sides of the weights) and inscriptions. Inscriptions are not otherwise known from press weights and this is another local characteristic. The decoration of press weights can be observed outside the survey area, but seldom beyond the central Anatolian region, and this re-enforces the impression that early Christian art and iconography often followed regional or provincial alignments, rather than looking to and following practice at Constantinople.

A similar point can be made with respect to the fluted capitals. They, too, predominate in central Anatolia, but not elsewhere, and certainly not at Constantinople. Small fluted capitals that likely belonged to liturgical church furnishings, with inscribed (Figs. 6-8) or otherwise decorated high tops, appear to have been an exclusively Anatolian fashion. In fact, they may have been specific to Galatia. In neighbouring Phrygia a different kind of special small column capitals for liturgical furnishings were commonly brought, ready-made, from the leading Anatolian quarry and workshop-complex at Docimium. ${ }^{64}$ However, the widespread use of fluted capitals in the hinterland of Ankara and elsewhere in Asia Minor was not a rural speciality, but probably followed urban examples, conforming to the distribution pattern of several different provincial styles in church building and decoration. ${ }^{65}$ In the case of the fluted capitals in the survey area, one may point to numerous examples known from Ankara itself, including a culmination of the style in the decoration of St. Clement. ${ }^{66}$ Overall, the finds from the hinterland of Ankara appear reassuringly normal in the way they relate to their local, provincial, and regional context, while differing from other regions of the early Christian empire. There is nothing odd about this regional differentiation. It reflects the way the church was organized in the early Byzantine period.

\footnotetext{
${ }^{62}$ /en.wikipedia.org/wiki/Kalecik_Karası. For antiquity, see especially the Life of St Theodotus 33 (fiveyear vintage).

${ }^{63}$ The same has been demonstrated for Byzantine stone carvings in Turkish villages around the ancient city of Aezani in Phrygia: Niewöhner 2007, 77-78.

${ }^{64}$ Niewöhner 2007, 128-129; Niewöhner 2013a, 237-242.

${ }^{65}$ Cf., for example, Strube 1993, 94-115; Niewöhner in press b.

${ }^{66}$ Niewöhner 2007, 173-175 cat. 396-400 and 403; Peschlow 2015, 222-224.
} 


\section{Bibliography}

Akyürek-Şahin 2004

N. E. Akyürek-Şahin, Phrygische Denkmäler im Museum von Bodrum, Olba 9, 2004, 137-149.

Altın - Şahin 2018

A. A. Altın - M. Şahin, Nikaia’nın Antik Dönemdeki Tarımsal Üretimine Dair İzler: Nikaia'dan Bir Pres Taşı, Uludağ Üniversitesi Fen-Edebiyat Fakültesi Sosyal Bilimler Dergisi 19, 2018, 815-827.

Ayalon - Frankel - Kloner E. Ayalon - R. Frankel - A. Kloner (ed.), Oil and Wine Presses in 2009 Israel from the Hellenistic, Roman, and Byzantine Periods, Oxford 2009.

Barsanti - Flaminio -

C. Barsanti - R. Flaminio - A. Guiglia, Corpus della scultura

Guiglia 2015 altomedievale 7. La diocesi di Roma. La 3 regione ecclesiastica, Spoleto 2015.

Bell - Ramsay 1909

G. L. Bell - W. M. Ramsay, The Thousand and One Churches, London 1909.

Börker 1965

C. Börker, Blattkelchkapitelle, Diss. Berlin 1965.

Breytenbach - Zimmer-

mann 2017

C. Breytenbach - C. Zimmermann, Early Christianity in Lycaonia and Adjacent Areas, Leiden 2017 (Ancient Judaism and Early Christianity 101).

Bricault 2005

L. Bricault, Receuil des inscriptions concernant les cultes isiaques, 3 vols, Paris 2005.

Drew-Bear 1994

T. Drew-Bear, Nouvelles inscriptions de Dokimeion, MEFRA 106, 1994, 747-844.

Eyice 1971

S. Eyice, Recherches archéologiques à Karadağ (Binbirkilise) et dans la région de Karaman, Istanbul 1971 (Istanbul Üniversitesi Edebiyat Fakültesi Yayınlarından 1587 = Türkiye'de Ortaçağ Sanatı Araştırmaları 2).

Fant 1988

J. C. Fant, The Roman Emperors in the Marble Business, in: N. Herz - M. Waelkens (ed.), Classical Marble, Dordrecht 1988, 147158.

Fant 1989

J. C. Fant, Cavum Antrum Phrygiae, Oxford 1989 (BAR International Series 482).

Feissel 2006

D. Feissel, Chroniques d'épigraphie byzantine 1987-2004, Paris 2006 (Monographies 20).

Frankel 1999

R. Frankel, Wine and Oil Production in Antiquity in Israel and other Mediterranean Countries, Sheffield 1999 (JSOT/ASOR Monograph Series 10).

Grégoire 1922

H. Grégoire, Recueil des inscriptions grecques chrétiennes de l'Asie Mineure, Paris 1922.

Hamilton 1842

W. H. Hamilton, Travels and Researches in Asia Minor, Pontus and Armenia, 2 volumes, London 1842. 
Hirschfeld 1888

Hirt 2010

Ivantchik - von Kienlin Summerer 2010

Ivison 2012

Keskin 2013

Keskin no date

Keskin 2015

Krautheimer 1986

Legrand 1897

Lewit 2020

Liljenstolpe 1996-1998

Macpherson 1958

Mitchell 1982

Mitchell 1993

Mitchell - French 20122019

Niewöhner 2007
G. Hirschfeld, Inschriften aus dem Norden Kleinasiens, Sitz.Berl. 2, $1888,863-890$.

A. M. Hirt, Imperial Mines and Quarries in the Roman World, Oxford 2010.

A. Ivantchik - A. von Kienlin - L. Summerer, Recherches à Kélainai - Apamée Kibôtos en 2008-9. Rapport préliminaire, Anatolia Antiqua 18, 2010, 109-140.

E. A. Ivison, Excavations at the Lower City Enclosure, in: C. S. Lightfoot - E. A. Ivison (ed.), Amorium Reports 3: The Lower City Enclosure, Istanbul 2012, 5-151.

E. Keskin, Çorum Ili ve Çevresinde Bulunan Zeytinyağı ve Şarap Üretiminin Bizans Dönemine Ait Arkeolojik Kantları, in: N. Türker - G. Köroğlu - Ö. Deniz (ed.), I. Uluslararası Karadeniz Bölgesi Kültür Kongresi, Karabük 2013, 372-386.

E. Keskin, Çorum Ili ve Çevresinde Bulunan Bizans Dönemine Tarihlenen Taş Eserler Üzerinde Görülen Bezemler, in: A. Özüdoğru (ed.), Çorum ve Kültür, Çorum no date, 233-239 (T.C. Çorum Valiliği Kültür ve Turizm Müdürlüğü Yayınlar1 9).

E. Keskin, Küçük Asya'da Kutsal Kent Euchaita ve Bizans Dönemi Taş Eserleri, ${ }^{2}$ Ankara 2015.

R. Krautheimer, Early Christian and Byzantine Architecture, 4th rev. ed., New Haven 1986.

E. P. Legrand, Inscriptions de Paphlagonie, BCH 21, 1897, 92-101.

T. Lewit, Invention, Tinkering, or Transfer? Innovation in Oil and Wine Presses in the Roman Empire, in: P. Erdkamp - K. Verboven - A. Zuiderhoek (ed.), Capital, Investment, and Innovation in the Roman World, Oxford 2020, 307-355.

P. Liljenstolpe, The Roman Blattkelch Capital, Opuscula Romana 21-23, 1996-1998, 91-216.

I. W. Macpherson, New Evidence for the Historical Geography of Galatia, PhD Cambridge 1958.

S. Mitchell, The Life of St Theodotus of Ancyra, Anatolian Studies 32, 1982, 93-113.

S. Mitchell, Anatolia: Land, Men, and Gods in Asia Minor 2. The Rise of the Church, Oxford 1993.

S. Mitchell - D. French, The Greek and Latin Inscriptions of Ankara (Ancyra), Munich 2012-2019 (Vestigia 62 and 72).

P. Niewöhner, Aizanoi, Dokimion und Anatolien. Stadt und Land, Siedlungs- und Steinmetzwesen vom späteren 4. bis ins 6. Jh. n. Chr., Wiesbaden 2007 (Aizanoi 1 = Archäologische Forschungen 23). 
Niewöhner 2013a

Niewöhner 2013b

Niewöhner 2014

Niewöhner 2016

Niewöhner 2017

Niewöhner 2018

Niewöhner 2020

Niewöhner in press a

Niewöhner in press $b$

Niewöhner - Vardar

in press

Nowakowski 2018

Paton - Hicks 1891

Peker 2020

Peschlow 2015
P. Niewöhner, Phrygian Marble and Stonemasonry as Markers of Regional Distinctiveness in Late Antiquity, in: P. Thonemann (ed.), Roman Phrygia, Cambridge 2013, 215-248.

P. Niewöhner, Bronze Age Hüyüks, Iron Age Hill Top Forts, Roman Poleis, and Byzantine Pilgrimage in Germia and Its Vicinity, AS 63, 2013, 97-136.

P. Niewöhner, Production and Distribution of Docimian Marble in the Theodosian Age, in: I. Jacobs (ed.), Production and Prosperity in the Theodosian Age, Leuven 2014, 251-271 (Interdisciplinary Studies in Ancient Culture and Religion 14).

P. Niewöhner, Die byzantinischen Basiliken von Milet, Berlin 2016 (Milet 1, 11).

P. Niewöhner, Das Rätsel der anatolischen Kreuzsteine, in: A. Külzer - M. Popović (ed.), Space, Landscapes and Settlements in Byzantium. Studies in Historical Geography of the Eastern Mediterranean Presented to Johannes Koder, Vienna 2017, 251-264.

P. Niewöhner, Byzantine Preservation of Ancient Monuments at Miletus in Caria. Christian Antiquarianism in Western Asia Minor, in: J. Borsch - O. Gengler - M. Meier (ed.), Die Weltchronik des Johannes Malalas im Kontext spätantiker Memorialkultur, Stuttgart 2018, 191-216 (Malalas Studien 3).

P. Niewöhner, The Riddle of the Anatolian Cross Stones - Press Weights for Church or Monastic Estates?, in: D. Moreau et al. (ed.), Archaeology of a World of Changes, Oxford 2020, 327-336 (BAR International Series 2973).

P. Niewöhner, The Regional Paradigm in Early Christian Art and Architecture. The Case of Anatolia, in: E. Akyürek et al. (ed.), Byzantine Anatolia: Space and Communities, Istanbul in press (International Sevgi Gönül Byzantine Studies Symposium 5).

P. Niewöhner, The Grave of St Nicholas, in: E. Akyürek (ed.), Byzantine Anatolia, Istanbul in press (Anatolian Civilisations 8).

P. Niewöhner - A. Vardar, Churches, Caves, and Fortifications in the Upper Siberis/Kirmir River Valley. On the Byzantine Settlement Archaeology of Rural Galatia, Central Anatolia, in press.

P. Nowakowski, Inscribing the Saints in Late Antique Anatolia, Warsaw 2018.

W. R. Paton - E. L. Hicks, The Inscriptions of Cos, Oxford 1891.

N. Peker, Agricultural Production and Installations in Byzantine Cappadocia: a Case Study Focusing on Mavrucandere, Byzantine and Modern Greek Studies 44/1, 2020, 40-61.

U. Peschlow, Ankara. Die bauarchäologischen Hinterlassenschaften aus römischer und byzantinischer Zeit, Vienna 2015. 
Russell 2013

Serres 1998

Strube 1993

Strzygowski 1903

Styan 1987

Şahin 2019

Tabbernee 1997

Tchalenko 1958

Vardar 2004

Vardar 2006

Vidman 1969

B. Russell, The Economics of the Roman Stone Trade, Oxford 2013.

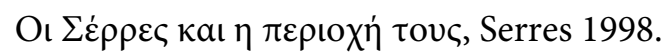

C. Strube, Baudekoration im Nordsyrischen Kalksteinmassiv 1, Mainz 1993 (Damaszener Forschungen 5).

J. Strzygowski, Kleinasien: ein Neuland der Kunstgeschichte, Leipzig 1903.

M. C. Styan, The Use of Pipe Ornament in Late Antique Architectural Sculpture, in: Fondation européenne de la science. Activité byzantine. Rapports des missions effectuées en 1983, 1987, vol. 2, p. 344-376.

M. Şahin, Bursa İli ve İlçeleri Arkeolojik Yüzey Araştirmasi - 2018 İznik - Yenişehir, AST 37/3, 2019, 83-99

W. Tabbernee, Montanist Inscriptions and Testimonia, Macon GA 1997 (Patristic Monograph Series 16).

G. Tchalenko, Villages antiques de la Syrie du Nord 3, Paris 1958.

L. E. Vardar, Galatia Bölgesi Kaleleri/Yerleşmeleri Yüzey Araştırmasi: Ankara ve Kurıkkale İlleri, 2004, AST 23/1, 2005, 267-283.

L. E. Vardar, Galatia Bölgesi Kaleleri/Yerleşmeleri Yüzey Araştırması: Ankara İli, AST 24/2, 2006, 79-100.

L. Vidman, Sylloge Inscriptionum Religionis Isiacae et Sarapiacae, Berlin 1969.

\section{Ankara'nın Doğusunda Kilise İnşası ve Şarap Yapımı Erken Bizans Dönemi’nde Orta Anadolu’nun Bölgesel Yönleri \\ Özet}

Bu makale Galatia'daki Ankara/Ankyra'nın doğusudaki komşu alanlarda yapılmış bir arkeolojik yüzey araştırmasıyla saptanmış Erken Bizans Devri’ne ait taş oyma eserler ve yazıtları hakkındadır. Bazı dilimli sütun başlıkları Erken Hristiyan kiliselerinin törensel (litürjik) düzenlemelerinin özelliklerinden olabilir. Aynı biçimde bazı şarap sıkma gereçlerinin ağılık taşları da Hristiyan simge ve yazıtlarla bezenmiştir. Kalecik/Malos'ta saptanan bir küme buluntu Ankyra'lı Aziz Theodotos dönemi olan dördüncü yüzyıl yaşamını yansıtır. Dolanmış yılan sembolünün işaret ettiği Asklepios ve Mısır Tanrıçası Isis'le bağlantılı antik tedavi yönteminin Hristiyanlık Dönemi’nde de sürdürüldüğü görülmektedir. Buluntular genel olarak bölgenin ünlü antik ve modern şarap üretim geleneğini ve sağlık kürlerinin burada sağlandığını kanıtlamaktadır. Oymaların biçimsel repertuvar ve üslûbu Erken Bizans İmparatorluğu'nun diğer kesimlerindeki örneklerden farklılıklar göstermekte olup bu ek özgünlük Orta Anadolu'ya kendi başına bir Erken Hristiyan 'Kunstlandschaft'ı (sanat bölgesi) olma hakkını vermektedir. Yazıtların çevirisi şöyledir:

s. 202, üst: Orogenes kızı Kale’nin adağını gerçekleştirmek için.

s. 202, alt: Gezgin (rahip) Eusebios'un adağını gerçekleştirmek için.

s. 210: Kutsal, kutsal, kutsal Efendi Sabaoth! Gökler senin şanınla dolu. Ey efendi, esirge! Hayat, $\imath$ ı̧ı! 
s. 211, üst: Kutsal Kudretli!

s. 211, alt: Immanuel!

s. 212: Tanrı kutsaldır!

s. 214: Ey Aziz Theodotos!, onların yardımına koş, zanaatkâr Antoninus ve Theodotos'un (yardımina), sağlikla!

s. 218: İyi talihle! Sentius oğlu Lucius, Efendi Isis için adağın yerine getirilmesi vesilesi ile.

s. 221: Aglaometis tüm 'Sınava Dayanıklı Şehit Kilisesi'ni süsledi.

Anahtar Sözcükler: Dilimli Sütun Başlıkları, Yazıtlar, Galatia, Malos, Sıkma Ağırlık Taşları, Taşra Arkeolojisi, Kirsal Arkeoloji.

\section{Church Building and Wine Making East of Ankara. Regional Aspects of Central Anatolia in the Early Byzantine Period}

Abstract

This paper reports early Byzantine carvings and inscriptions that were found in a survey of the eastern vicinity of Ankara/Ancyra in Galatia. Some fluted column capitals can be attributed to liturgical furnishings of early Christian churches. Some weights for wine presses are likewise decorated with Christian symbols and inscriptions. A cluster of finds from Kalecik/Malos echoes the fourth-century Life of St Theodotus of Ancyra. The symbol of a coiled snake refers to an ancient healing tradition that was originally associated with Asklepios and the Egyptian goddess Isis, but appears to have continued in Christian times. Overall, the finds confirm the area's ancient reputation for wine making and show that healing cures were also provided. The formal repertoire and style of the carvings differ from other parts of the early Byzantine empire and lend distinction to central Anatolia as an early Christian Kunstlandschaft in its own right.

Keywords: Fluted Column Capitals, Galatia, Inscriptions, Malos, Press Weights, Provincial Archaeology, Rural Archaeology. 